\title{
Ṭabūn, Tannūr or Mustawqad? Fire Devices and Their Use in the Early Islamic Period
}

\author{
Hagit Nol \\ Post-Doc, Centre de Recherches en Archéologie et Patrimoine, \\ Faculté de Philosophie et Sciences sociale, Université libre de Bruxelles, \\ Brussels, Belgium \\ nolgit@yahoo.com
}

\begin{abstract}
Ovens, hearths and furnaces were used by early Islamic societies for baking, cooking, and the production of various artefacts. The archaeological evidence from one research area in central Israel, from the seventh-eleventh centuries, accordingly presents a variety of fire installations. This paper offers an interpretation of their function through the analyses of terminology in contemporary texts, ethno-archaeological data, and spatial relations in the archaeological record. The paper suggests that domestic baking and cooking left almost no remains in the archaeological context. Instead, fire installations in the research area were almost exclusively related to crafts.
\end{abstract}

\section{Keywords}

Big Data - spatial archaeology - ethno-archaeology - Early Islam - Palestine - țabūn - crafts pottery production

Archaeologists, perhaps more than any other practitioners of a discipline that studies the human past, are interested in the purpose and operation of technologies. Technologies reflect both daily life and the sources of income of ancient individuals, settlements, and regions. Installations (e.g. winepresses) and specific remains (e.g. pottery waste) enable the reconstruction of production activities, which play a part in the economic texture of places. The function of some installations is unquestionable, such as that of wells, but most have uncertain purposes or operation methods. For example, built channels that are covered by stones can be interpreted diversely as conduits for the supply of drinking water, as irrigation channels, as tunnels for greywater, or as sewage lines.

The solutions for interpreting the purpose of installations are not straightforward. Scholars compare installations and related activities to the ones used and fashioned by modern societies ("ethno-archaeology"), to devices in semi-contemporary art (e.g. Roman mosaics, Ottoman miniature paintings), or to facilities described in narrative sources, documentary evidence and legal literature ("ethno-history"). Other studies test these theories physically on similar devices ("experimental archaeology"). This paper will follow two of these methods, ethno-archaeology and ethno-history. However, it also confronts the inherited challenges of these analogical tools, as will be discussed 
shortly. In addition, it utilizes two less-common methods of analysis: terminological and spatial.

One group of installations that are commonly found in excavations from the prehistory onward is fire-related. The fire installations in the focus of this article derive from sites of the seventh-eleventh centuries CE (early Islam) in one area in central Israel. The main aim of this study is to interpret their function. A supplementing question involves the reasons of the inhabitants for preferring one installation over another, or for employing installations in parallel.

In archaeology, scholars often hope to reveal in situ circumstances, reflecting Binford's "Pompeii Premise" (Binford, 1981). Accordingly, animal bones inside fire installations, for example, might signify cooked meat, or at least fuel (Balossi Restelli, 2015: 142; Rova, 2014: 132). Likewise, built fire installations with remains of pottery or glass in their surroundings are interpreted as kilns. Correspondingly, the absence of finds inside these installations or in their immediate surroundings allegedly represents their relation to bread baking, which indeed leaves nothing but ash (e.g. Crawford, 1981: 108, 114). In reality, the life-cycle of any archaeological artefact is complex and often remains unknown to the excavator (Schiffer, 1987). Ovens could be secondarily used for storage, for example (London, 2000: 108; Van der Steen, 1991: 137), though not necessarily by concurrent residents. Moreover, people tend to regularly keep their surroundings clean, so household activities are expected to only seldom leave traces (LaMotta and Schiffer, 1999).

Some scholars sketch a direct line between the archaeological remains and modern ovens studied through ethno-archaeology. Using phrases such as "[they] are still in use" (e.g. McQuitty, 1984: 259; Rova, 2014: 121; Smogorzewska, 2012: 242; van der Steen, 1991: 135), these studies thus suggest a technological stasis for hundreds and even thousands of years. In contrast, Ebeling and Rogel (2015) criticize this method and call for a historical approach. A number of research works indeed find typological shifts in ancient installations over time (Balossi Restelli, 2015; Parker and Uzel, 2007; van der Steen, 1991).

Pursuing the domestic-bread interpretation of ovens, scholars who face the clustering of these installations in non-domestic contexts in the Near East explain them also as food related. The food-production interpretations include the notions of commercial quarters of bakers, centralized bakeries, shared spaces for ovens, or cooking areas for seasonal workers (Crawford, 1983; Rova, 2014: 141, 144; Van der Steen, 1991: 142).

The simplistic analogy between modern ovens and ancient fire installations is not the only one. In parallel, modern terminology gets combined with ancient terminology along with its imagined descriptions in texts. The two analogies are then integrated into one interpretation. The clearest example is pinning the name of one of the modern domestic ovens, țabün, to its earliest possible citation. The term in plural (al-tawābin) is mentioned by the geographer al-Maqdisī in the tenth century. Based on translations of the Arabic text, some scholars hold to the resemblance between the modern and the virtual tabūns in their baking technique (placing dough loaves over hot pebbles) (Dalman, 1935: 80, followed by Rova, 2014: 126). They ignore the significant differences in form: the modern tabün is a built oven and the ancient one is an ephemeral stone pavement. They also ignore the variety of meanings of tabün in modern communities (at Ebeling and Rogel, 2015: 329). Nuha Khoury (1998) discusses a similar problem regarding the mihrab in mosques. Thus she advocates a clear division between "term," "form" and "function"; each category has its own history and the meeting point of the three might be the result of a later process.

Another pitfall in linking archaeological finds with textual descriptions, particularly in the case of installations, is the imbalance of their survival. On the one hand, many technologies leave physical traces, but are silent in the sources (e.g. pottery production) 
and on the other hand, many of the described industries leave scarce remains or none (e.g. textile). Two relevant examples of industries with a produce absent from the archaeological record are dyeing and soap production. Some installations are associated with these activities (e.g. Gat, 2007: 46-8), ${ }^{1}$ but their interpretation is debatable. Their descriptions in texts point to general devices, which would be hard to detect.

My approach is twofold. First, following Ian Hodder, naming archaeological finds and interpreting their function is postponed until their context is better understood (Hodder and Hutson, 2003: 167-9o). Thus, I do not use the term "kiln" in the archaeological record, for example, but neutral names invented for that purpose. Moreover, instead of drawing direct analogies between individual specimens in the different source groups (i.e. archaeology, ethno-archaeology and ethno-history), I analyze each corpus independently and then compare their complete sets.

To that end, a broad scale of "Big Data" was collected for each source group separately. To provide a sufficient context, the scope of sources used was expanded in some cases far beyond the research area. The relevance of the data can be proved only after the fact, thus some elements are redundant. As an example from ethno-archaeology, surveys of all the fire apparatuses that communities used during the ethnographers' fieldwork are more valuable than studies of bread baking ovens or pottery kilns alone. The former represent a full range of parallel functions, which provides a complete context, even though some of the activities and apparatuses are irrelevant to the archaeological case study. To follow such an intellectual process can be tiring for the reader, but it ensures a higher level of objectivity and transparency.

A supplemented approach follows Khoury's division; I separate the "terms" in written sources from physical characteristics ("form") in archaeological contexts, and from "function" as expressed in ethnography and in texts. As will be presented, the ancient tannür did not have one form or even one function, and bread was not necessarily baked in a built fire installation. Therefore, the name and function of archaeological fire places with their various types, in different periods, should be justified. Naming them with a modern term before such a justification, and even after, is misleading.

Regarding the terminology used in the article, the term "installation" is principally reserved for archaeological finds, while other terms such as "device" or "apparatus" are used with texts and ethnography. In this context, "hearth" means fire remains without a built installation. Importantly, no effort was made to characterize devices, or spaces, as "rural" or "urban." If one chooses to follow such a dichotomy, one must first clearly define its classifications and then consistently compare it to the historical or archaeological context (e.g. Nol, 202O). As this might be invalid categorizations, and surely restricting, I chose to avoid such labels.

In the following, I first study the terminology of relevant apparatuses in semicontemporary texts, including their descriptions and assigned function. The texts indicate a variety of oven forms and baking techniques, the common use of ephemeral devices and portable utensils, and the possibility to share an oven or use baking services. At the same time, they show the use of furnaces for "industry" and for bathhouses, along with activities, which require no device such as soap production and dyeing.

Second, I look at ethnographic studies in the Near East, Afghanistan, and Morocco to understand function and operation of fire devices, along with their residues. These studies show, surprisingly similar to the ethno-history, a variety of oven forms and baking techniques, the common use of ephemeral devices and portable utensils for domestic 
cooking, the possibility to share ovens or to use professional baking services or bakeries, and the uniformity of pottery firing in a kiln or a bonfire. In addition, it demonstrates quick changes in the preference of one device over another in the food-production sphere. Most significantly to the archaeologist, they present the scarce remains of domestic cooking and household pottery firing, in contrast to "industrial" kilns.

Third, I classify fire remains in the research area into three built types, along with general hearths, and identify their spatial relations. This section connects most fire installations (FI) to specific crafts and activities. In contrast, one built type (found only once on most sites) shows no relation to any other remains. More general observations include the absence of any built FI on a number of excavated sites, the clustering of FI on the edges of a number of sites, and the absence of fire remains in "residential areas" inside the site/s of Ramla. The patterns together suggest that most fire remains in the archaeological record result from activities related to crafts and that domestic cooking and baking is mostly absent. This interpretation correlates with the ethnoarchaeological and ethno-historical evidence that pointed to the common usage of devices other than ovens at the household. Even more distinct is its accord with the limited domestic residues vs. visible industrial remains according to the ethnographic evidence.

\section{Ovens and Kilns: the Textual Evidence}

The relevant textual and artistic evidence of technologies is very rich, but mostly fragmentary. Social historians, who investigate daily life in early Islam or earlier periods through texts, often use the Geniza (tenth-eleventh centuries), Talmud Bavli (thirdsixth centuries), Pliny the Elder (d. 79), or Arabic geographers (ninth-fifteenth centuries). This study employs additional sources, including the muhtasib manuals by al-Shayzarī (d. 1193), the rabbinic responsa of the eighth-tenth centuries, the lexicon Kitāb al-Mukhașsaṣ (The Book of the Designated) by Ibn Sīda (d. 1066), a cookbook attributed to Ibn Sayyār al-Warrāq from the tenth century, and the alchemy of al-Rāzī (d. 925).

These sources were chosen for their relevant depictions of daily life in Palestine, or their relatively rich descriptions of fire activities elsewhere. The evidence, as we shall see, is so scarce that the temporal and geographical contexts had to be expanded. Due to the wide contexts and scarce data, variations and nuances caused by time or space were possibly overlooked. Nevertheless, the method does highlight correlations and discrepancies, which could not have been achieved with a smaller sample.

The scattered information on fire apparatuses surfaces in various sources. The more common terms in Arabic are tannür, atūn, furn, kūr and mustawqad. They involve cooking and baking, heating the bathhouse, pottery firing, and many more industries. The common terms in Hebrew are tannûr and kîrâ for food, and kivshān for pottery. These terms will be presented shortly according to their possible form and function. A clear terminological cut can be made between installations for food preparation, or alchemy, and furnaces. The latter are utilized in metal smelting, in pottery firing, and in the bathhouse. A typology of the imagined apparatuses suggests further division between built implements and portable devices. A later comparison with ethnographic evidence supports such a typology. The comparison also demonstrates how most installations leave no physical traces.

In the entry mațakh (kitchen) in the Encyclopedia of Islam, second edition, Waines introduces two terms for food ovens based on Ibn Sayyār: tannūr for bread and mustawqad for cooked dishes (Waines, 1991). However, Table 1 and the following examples offer a more complex interpretation for tannür, suggesting a dual meaning. The term 
TABLE 1

Terminology and function of fire apparatuses in the varied sources

\begin{tabular}{|c|c|c|c|c|c|}
\hline Term & Geonim & al-Rāzì & Ibn Sayyār & al-Maqdisī & al-Shayzarī \\
\hline tannūr & $\begin{array}{l}\text { baking, } \\
\text { heating }\end{array}$ & baking & $\begin{array}{l}\text { baking, } \\
\text { cooking }\end{array}$ & baking & $\begin{array}{l}\text { baking, } \\
\text { cooking, } \\
\text { perfumes- } \\
\text { related }\end{array}$ \\
\hline furn & $\begin{array}{l}\text { baking } \\
\text { (fûrnî) }\end{array}$ & & $\begin{array}{l}\text { baking } \\
\text { (or furnī) }\end{array}$ & $\begin{array}{l}\text { baking } \\
\text { (al-ifrana) }\end{array}$ & baking \\
\hline mustawqad & & alchemy & cooking & & \\
\hline țābashdān & & $\begin{array}{l}\text { cooking, } \\
\text { alchemy, } \\
\text { minting }\end{array}$ & & & \\
\hline tāabaq & $\begin{array}{l}\text { baking } \\
(\text { țapaqâ) }\end{array}$ & & baking & & \\
\hline țabūn & & & & $\begin{array}{l}\text { baking, } \\
\text { cooking }\end{array}$ & \\
\hline mulla & & & baking & & \\
\hline kîrâ & $\begin{array}{l}\text { baking, } \\
\text { cooking }\end{array}$ & & & & \\
\hline näfikh nafsihi & & alchemy & cooking & & \\
\hline kānūn & $?($ kanûnâ $)$ & & cooking & & \\
\hline$k \bar{u} r$ & & $\begin{array}{l}\text { alchemy, gold } \\
\text { smithing }\end{array}$ & & & $\begin{array}{l}\text { gold } \\
\text { smithing }\end{array}$ \\
\hline atūn & & pottery, bones & & & $\begin{array}{l}\text { bones, bath } \\
\text { house }\end{array}$ \\
\hline kivshān & pottery & & & & \\
\hline
\end{tabular}

was first used for a specific baking device, and later mainly as a general term for any cooking installation. Indeed, some rabbinic sources relate the term solely to bread baking, to the bakery, or to keeping food warm during Shabbat. ${ }^{2}$ It seems to be a specific device, distinguished from kîrâ or fûrnî, and it can be communal, as in "you should bake, ten women, your bread in one tannûr."3 A more general meaning for tannūr, still for baking, is offered by al-Shayzarī as a synonym for furn: "when the baker has finished lighting the tannūr he should first wipe inside it with a clean rag before baking the bread," then make wide holes in the roofs of the furn, for the smoke to come out (al-Shayzarī: 22, translated at Buckley, 1999: 47). Likewise, al-Maqdisī (d. after 99o) uses three synonyms in the context of domestic cooking in Syria: "and they have al-ifrana, the villagers in particular, al-tawābin, which is a small tannūr in the ground and furnished with pebbles (ḥaṣā)" (al-Maqdisī: 183).

Still, other cooking activities are also related to tannūr. Most distinctly, the recipes by Ibn Sayyār involve varied cooking techniques in it (Ibn Sayyār al-Warrāq: 176, 339, 374). Moreover, the synonyms al-Rāzī uses for tannūr (mustawqad and nāfikh nafsih) are never linked to baking (Stapleton et al., 1929: 383-4). The general meaning of the term is also implied in its varied operations in the rabbinic texts: the metal tannûr was fueled externally and the clay tannûr was stoked internally. ${ }^{4}$

The designated term for a baking device is furn (Heb. fûrnî). Ibn Sīda explains it as the place where Syrian bread ( $a l-k h u b z$ Shämiyya) is baked (Ibn Sīda, vol. 5: 7). Two pieces of evidence imply it was specifically a bread oven and not a bakery, and that it was privately owned: it is mentioned in one rabbinic text about properties, which cannot be 

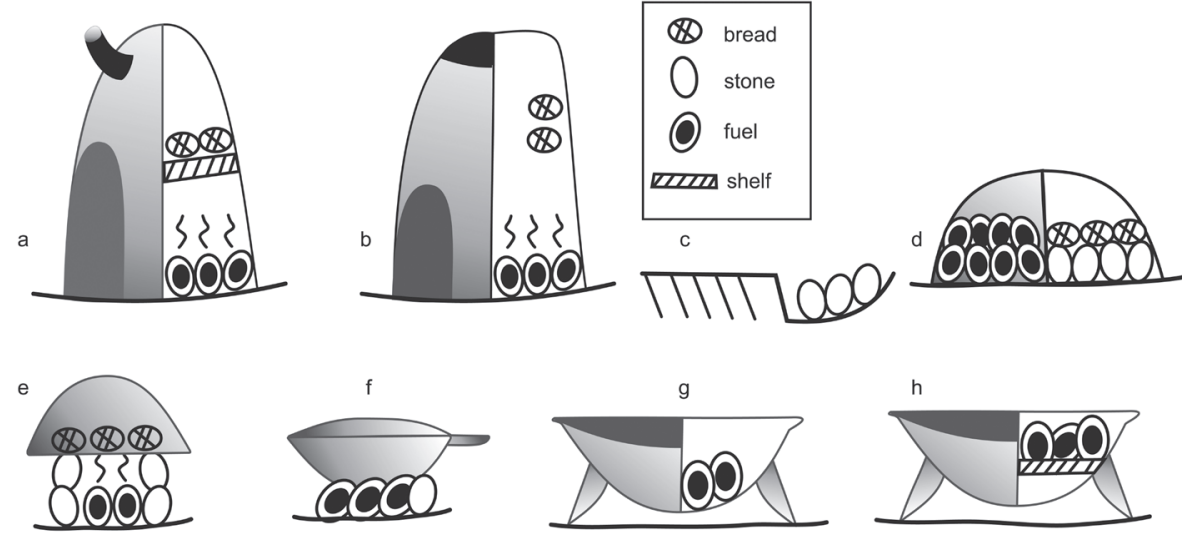

rented out to non-Jews, ${ }^{5}$ and al-Shayzarī notes oven-keepers ( farrāninn) who bake the doughs of different customers and get paid with a portion of dough (al-Shayzarī: 24, translated at Buckley, 1999: 49). It seems that in the early Islamic period furn was not a common innovation, at least not everywhere. The rabbis answer in the Jewish responsa, for example, is that they "do not possess a fürnî and do not know what it does" (Änû ên 'immānû fûrnîwe-ên ānûyôd'în me'aseyha). ${ }^{6}$

The fragmentary details on each of the cooking apparatuses enable a sketchy typology (Fig. 1). The significance of this division lies on the level of the physical remains each type leaves. The four main types are: built structures, ephemeral structures, portable utensils that are placed on a fire, and others that carry fire. The built apparatuses are the only group that is expected to be distinctly recognized in an excavation. It includes the mustawqad and the furn. According to al-Rāzī, the mustawqad is a cylindrical structure with one door for stoking, a hole for ventilation, and a pit underneath, used in various techniques and with various contents (Stapleton et al., 1929: 355, 381-3). Similarly, the mustawqad of Ibn Sayyār has one high rectangular-trapezoid type, with an outlet for smoke, and a cylindrical type (Nasrallah, 2010: 86-90; Zaouali, 2007: 52). The furn has a shelf, and holes in its roof (al-Shayzarī: 22, translated at Buckley, 1999: 47).

The second type is the ephemeral built structures, which includes what seem to be, subjectively speaking, simple arrangements and constructions. It comprises a pit of stones (țabūn or mulla) and maybe the țābashdān. Al-Maqdisī explains that al-tawābin are pebbles, stoked with dung $(a l-z i b l)$, whereupon the dough loaves are placed, as well as lentils and other dishes (al-Maqdisī: 183). Nasrallah interprets Ibn Sayyār's mulla similarly, as a "pit with hot ashes and stones" (Nasrallah, 2010: 118, 335). The țābashdān/ tabiștān might fit into this group, but can alternatively be a portable apparatus. It is an "inverted" device, in which the fire is placed on the top. It is used for superficial heating or for the removal of greasy surfaces. Al-Rāzī writes that similar facilities are used by mint masters to soften dirhams by fire, and by food hawkers (Stapleton et al., 1929: 359, 384). Moreover, one rabbinic text offers two cooking methods directly on the ground using embers (gehālîm) for cooking an egg, or placing "fire" beneath a cauldron ( $q^{e}$ derâ) and stabilizing it with stones (avānimm mikān wu-mikān). ${ }^{7}$

The next two groups of apparatuses are portable. Portable devices placed on fire include țābaq (Heb. țapaq $\hat{a}$ ) and varied utensils. The clay țapaqâ is stoked from underneath, and the bread is baked on its upper side. ${ }^{8}$ Nasrallah translates țābaq as a "large flat pan" that is used for baking bread (Nasrallah, 2010: 118, 410). In the drawing (Fig. 1.e), the device has a domed shape, but it similarly could be flat. Other portable devices are recommended for the alchemist: a variety of crucibles such as jugs (kizzān), two-part vessels with a punched upper part (būt-bar-būț), a rag or a bag (șurra or yușrra), glass flasks (qannānī) and other (Stapleton et al., 1929: 354-8, 379-84).
FIGURE 1

Imagining fire apparatuses according to the textual evidence Details: a) furn; b) mustawqad or tannūr; c) țabūn or mulla; d) țābashdān?; e) țābaq; f) cooking on fire; g) pot with ash (or charcoal); h) näfikh nafsihi (with a cover), kānūn or kîrâ 
Portable apparatuses that carry fire mainly include kîrâ, näfikh nafsihi, and its synonym kānūn (Heb. kanûnâ). Näfikh nafsihi is described by al-Rāzī as a device that stands on three legs, has a grate $(k \bar{u} w a)$ in its bottom center, a cover, and holes in the grate and on the legs. It is stoked with charcoals and can exploit breezes. About a century later, al-Khwārazmī calls the same device kānūn (Stapleton et al., 1929:359-63, 384). The synonymy is repeated by Ibn Sayyār, who advises using näfikh nafsihi or kānūn 'ajlān in one meat recipe (Nasrallah, 2010: 284). In the rabbinic texts, the term kanûnâ relates to a portable device with wood and ash..$^{9}$ A much more common term in Hebrew is kîrâ (pl. kîrâyim), which is made of stone or metal. It is chiefly used for the cauldron to be placed on its top over embers, but can be used also for baking. ${ }^{10}$ Another portable device is a pot with ashes that is recommended to the beginner alchemist (Stapleton et al., 1929: 381-4).

Information on furnaces is much more scarce and does not allow their reconstruction. In addition, it is not clear if the terms are typological or functional. According to al-Rāzī, the kūr (pl. kirān) has a cover and a perforated container (māsik) fitted in the interior. Substances such as iron or steel should be smelted in large kirān (Stapleton et al., 1929: 379). Next, "the (alchemical) atūn is exactly like a potter's atūn except that it is smaller. You place in it whatever you desire to calcine, and keep the fire burning until the substance is calcined." Thus, the țäbashdān (that is fueled externally) is "an inverted atūn" (Stapleton et al., 1929: 359). Illustrations from the sixteenth century demonstrate two different apparatuses named atūn: one for glass manufacturing, with two shelves and two chimneys, and a smaller one for glazed jewelry (al-Hassan and Hill, 1986: 154, 167). The earlier rabbinic sources, according to Brand, distinguish between the kûr or bôr of the glass makers, ${ }^{11}$ and the kivshān of the glass-vessel craftsmen (Brand, 1978: ${ }_{142-3)}$. In the later rabbinic responsa, kivshān is linked to pottery. ${ }^{12}$ At least two sources relate burnt bones to atānīn: apothecaries could fake bamboo with it; and the recipe for mercury required it together with fresh bones (al-Shayzarī: 73, translated at Buckley, 1999: 66; Stapleton et al., 1929: 386). The term atūn is also related to heating the bathhouse. Al-Shayzarī instructs on the amount of fuel (wuqūd) in the furnaces (al-attān), which must provide the right temperature (al-Shayzarī: 87-9, translated at Buckley, 1999: 104-7).

Table 2 summarizes the varied terms and their possible function. Designated baking was done in the furn, but other devices were additionally employed: a built oven fueled internally (tannūr or mustawqad), an oven stoked externally (țābashdān), a hearth (tabūn or mulla), or a portable surface (țābaq). Domestic cooking used either the warm oven after baking, or a portable brazier (näfikh nafsih or kānün). Finally, smelting was conducted in a possibly portable melting pot $(k \bar{u} r)$, whereas the bathhouse and most crafts used the furnace $(a t \bar{n} n)$.

TABLE 2

A summary of terms and functions of fire apparatuses

\begin{tabular}{|c|c|c|c|}
\hline Arabic & Hebrew & Function & Translation \\
\hline tannūr, mustawqad & tannûr & domestic cooking & built oven \\
\hline țābashdān & & domestic cooking & oven \\
\hline țabūn, mulla & & domestic cooking & hearth \\
\hline furn & fûrnî & baking & bread oven \\
\hline näfikh nafsih, kānūn & kîrâ, kanûnâ & heating, cooking & portable brazier \\
\hline țābaq & țapaqâ & baking & baking surface \\
\hline$k \bar{u} r$ & & metals softening & a melting pot? \\
\hline$a t \bar{u} n$ & kivshān & pottery, glass, bones, bathhouse & kiln, furnace \\
\hline
\end{tabular}


In addition to cooking or heating, the sources present two explicit uses of fire without explicitly mentioning a device: dyeing and soap production. In Palestine, dyeing or the production of dyes is ascribed chiefly to al-Ramla and to its neighbor Ludd/Diospolis, for example in Talmud Bavli (Avi-Yonah, 1966: 196), or by al-Balādhurī (d. 892: 143). Dyeing used to include two chief steps: soaking the threads, cloth or garment in a liquid, which would assist in absorbing the dye (mordant), then soaking it in the dye (al-Alī, 2003: 132; Forbes, 1964:134-5). According to Pliny the Elder, purple dyeing involved a pot with water that was heated by a pipe from some distant furnace. Moreover, a wall picture in Pompeii shows a dye vat on a furnace (Forbes, 1964: 116, 132). Recipes of dyes in Greek, on the Papyrus Holmiensis (the fourth century), mention boiling the dye over a fire, or using hot water. The containers that are mentioned in the recipes were translated as "pot" and "kettle" (German: Topf and Kessel) (Caley, 1926; Lagercrantz, 1913: 200-30). For dyeing in the thirteenth century, for which it was claimed fake dyes were used, the dyers employed large mobile containers (al-khābiya) (al-Shayzarī: 72, translated at Buckley, 1999: 92), but warming water is not specified. In short, the textual evidence points to a process which necessitates non-distinctive elements - mobile containers and fire.

The export of soap is also associated with al-Ramla in tenth and eleventh-century sources (al-Maqdisī: 18o; Gil, 1983: 254). In principle, soap is produced through a chemical process of mixing fats or oils with alkali salts. That mixture splits into alkali salt of fatty acids, which is the soap, and glycerol. The salts can be of lye $(\mathrm{NaOH})$, soda $\left(\mathrm{Na}_{2} \mathrm{CO}_{3}\right)$ or any other, gained from minerals or plant ashes (Konkol and Rasmussen, 2015). Al-Rāzì describes the process of saponification of olive oil, which he entitles "the creation of salts with oil." He explains that one must "take food salt and make it into a paste with olive oil and heat it for one night with dung fire in a luted pot, which has its head closed. Do this seven times, it will melt and flow" (Stapleton et al., 1929: 393). The described process of heating oil with salt requires a hearth and containers, which cannot, in principle, be specified for that purpose archaeologically.

Ethno-Archaeological Evidence of Fire-Related Activities

Ethno-archaeology has undergone strong criticism over the years, being blamed chiefly for conducting simplistic analogies and projecting the present onto the past (Wendrich, 2002; Wylie, 1985). One of the difficulties is proving the ethnographies of specific target groups as relevant to the archaeological comparison (e.g. Lyons and Casey, 2016). Compelled to limit the study domain, I have chosen to look at relevant ethnoarchaeological studies mainly from the Mediterranean and the Middle East, as they share a similar climate and landscape with the research area. This ecological analogy is not immune to criticism either (Wylie, 1985: 101). However, the wide context and varied case studies I utilize should balance most biases. Another precaution is the avoidance of a direct analogy with archaeology and the attempt to extract information from ethno-archaeology in its own context. At any rate, the distance from Morocco or Iraq to Israel is less relevant than the contribution of these studies to our research question.

The main aim of this section it to present various fire-related activities by modern communities in what can generally be defined as pre-industrial economies. Unfortunately, only little attention had been paid to "trash handling" in time and space, including the disposal of ash, or the fate of charcoal and broken ovens. Three of the studies I looked at offer an overview of various fire apparatuses and usages in the domestic sphere from present-day Morocco (Zapata Peña et al., 2003), from Iraq in the 1970s (Ochsenschlager, 1974), and from early twentieth-century Palestine (Dalman, 1928 , 1935). These studies show a range of activities and installations that communities 
FIGURE 2

Fired vessels inside kiln, Jizza, Jordan

COURTESY OF MARIA-LOUISE SIDOROFF

FIGURE 3

The kiln during firing, Jizza, Jordan

COURTESY OF MARIA-LOUISE SIDOROFF enjoy and exploit in different situations and for different needs. Another set of publications focus on bread ovens in Egypt (Rizqallah and Rizqallah, 1978), Jordan (McQuitty, 1984), Syria (Mulder-Heymans, 2002), and Turkey (Balossi Restelli, 2015: 142; Parker and Uzel, 2007). Two of the domestic case studies are introduced in detail shortly, followed by additional examples. Finally, a number of studies focuses on workshops of specific industries, mostly on pottery.

Ethno-archaeological inquiries on pottery firing were conducted, as examples, in Turkey (Batmaz, 2019), Syria (Bresenham, 1985), Palestine (Crowfoot, 1932), Jordan (Sidoroff, 2015), and Egypt (Henein, 1997; van der Kooij and Wendrich, 2002; Nicholson and Patterson, 1985). The studied pottery workshops went through the complete production process, including clay preparation, vessel forming, and firing. Most workshops used updraft kilns, where the pottery is stacked on a shelf from an upper opening (Fig. 2) and the fuel is stoked into a firebox below, which is sometimes dug in the ground. The main categories where these cases differ are the upper coverage of the vessels during firing (without, with a layer of sherds, with a slip and a layer of sand, or with a metal sheet, Fig. 3), the presence or absence of holes in the shelf, and the specific timing of the firing process, including drying the vessels before firing and letting the kiln cool afterwards. The large size of these kilns, at least $4 \mathrm{~m}$ in diameter, helps to gain the right temperature and thus to minimize cracks in vessels (Batmaz, 2019).
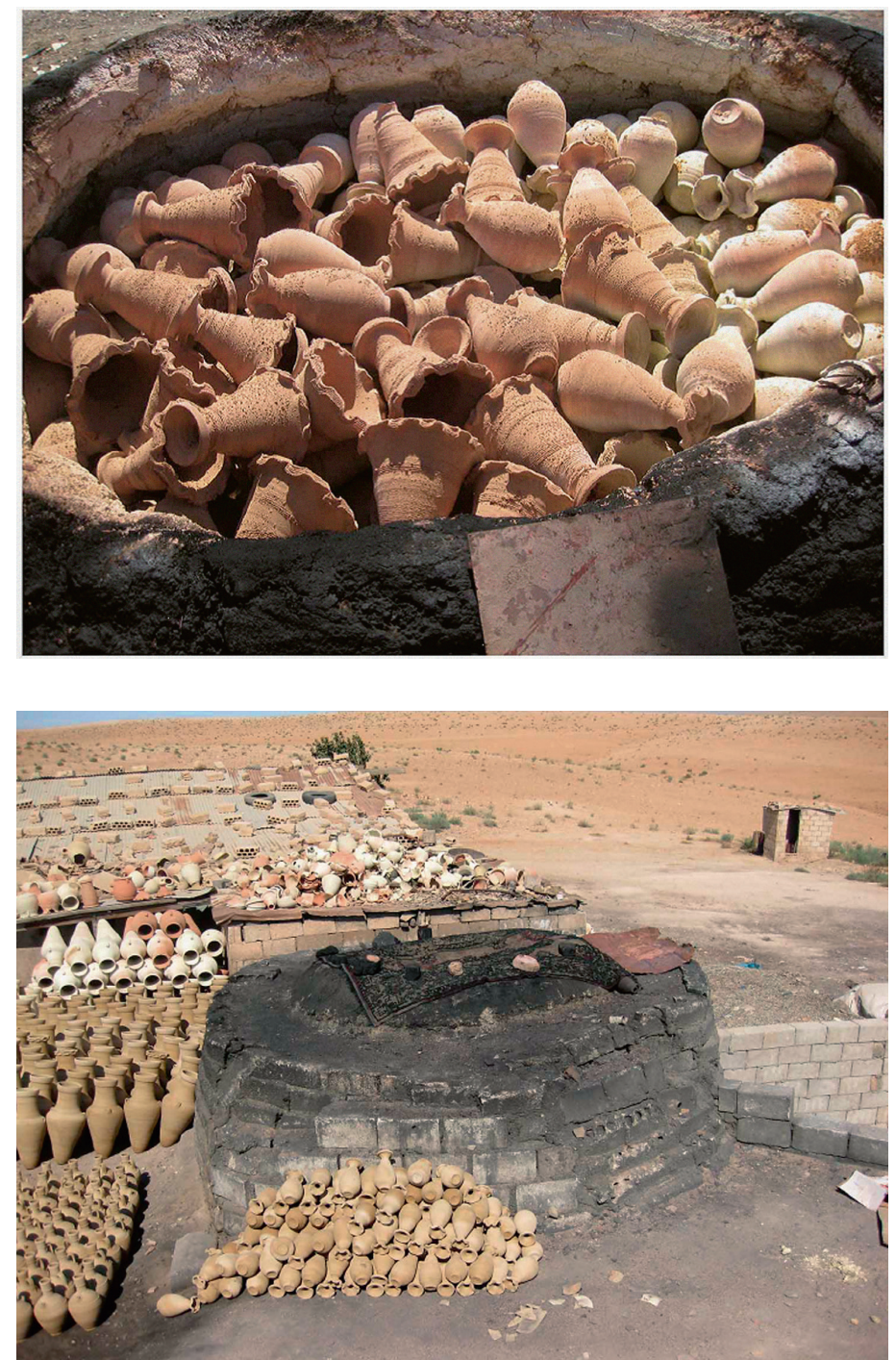
One workshop in Cairo used a smaller kiln besides two big devices (van der Kooij and Wendrich, 2002). Two other workshops, in Bușrā (Syria) and Sinjil (Palestine), are a one-woman operation. Similar to the households in Morocco, which will be discussed shortly, these workshops did not fire ceramics in a built kiln, but in a bonfire. The vessels were organized within a circle of big stones and covered by dung cakes or dried branches (Bresenham, 1985; Crowfoot, 1932). Interestingly, in Sinjil, before firing the vessels, they were "smoked" in the "oven-house," probably the shed for the domestic baking oven.

Ethno-archaeological works on metal, glass and soap production seem to be scarce. Regarding metals, one case study from modern Cairo presents a gas-operated melting furnace that is a pit in the workshop hall with an adjacent chimney. Brass is melted in it in a fifty-liter crucible (Shalev and Freund, 2002). Also in Cairo, a glass workshop was thoroughly documented, showing a complex rectangular furnace of $2.5 \mathrm{~m}$ in length and $1.2 \mathrm{~m}$ in height. The firebox is situated in the middle of the furnace, while other parts provide varied levels of heat for melting the glass through multiple openings (Henein and Gout, 1974:1-11). A similar operation was observed in Herat, Afghanistan, where the craftsmen produce both glass from raw materials and glass vessels (Brill, 1979. See also the film: The Corning Museum of Glass, 1979). Details on a soap factory in Jaffa are presented in a semi-popular book on nineteenth-century Palestine. In that workshop, lime was mixed with ashes of local plants and with water and was then cooked with olive oil for eight to twelve days in a huge copper container. The fire device is not specified (Avitsur, 1976: 265).

Studies in the domestic sphere demonstrate much more variation of fire installations for cooking and baking. The most comprehensive study for our purposes was conducted in the Jebala region, Northern Morocco (Zapata Peña et al., 2003). During fieldwork in a number of villages in the region, households showed the usage of four chief types of installations. For cooking and water boiling, braziers (mishmar) and winter/summer ephemeral devices (kanun) were used. In the past, bread had been baked on the ground using a pan (maqla), but it was baked in ovens during the time of research (with no terminology noted). The fourth type is an open fire, $30-50 \mathrm{~m}$ from the house, for firing pottery. The apparatus is made of a stone circle and an inner circle of wood. The vessels are placed inside, on and between them dry dung cakes are situated, and above them fresh dung is placed for slow and stable burning and slow cooling. After the main firing, the operation is left to cool overnight. Thereafter, the vessels are brought to the market. Only stones are left in place. Charcoal and ashes are collected for secondary use and other remains are disposed nearby. For a small number of vessels, only a domestic hearth is used to fire them.

In Syria, ethnographic research has focused on bread baking in different regions (Mulder-Heymans, 2002). During the time of research, the households of the various communities had either a single permanent high cylindrical oven (tannūr), three permanent concurrent ovens (each for a different type of bread: tannür, țabün and waqdiya), or a portable utensil (șajj). The ovens were located outside the house, sometimes very far away. When baking was done, the hot tannür often served for heating a pot. In the village Abtaa, home ovens operated simultaneously with a village bakery and with a business where one woman baked the dough of five families. The village Tell Mardikh had ovens in the past, but during this research used the more fuel-economic portable device.

These and other ethno-archaeological studies display a variety of devices that sometimes operated simultaneously in single households or in one area. It also indicates the popularity of portable devices in domestic food production. Bread baking was 
conducted either on portable utensils or in clay ovens with a dome or cylinder shape, on their floor, walls or on a designated shelf. Cooking was often done in the same ovens after baking or on portable devices. In Tell al-Hiba in southern Iraq, the main domestic installations included a clay brazier for cooking and water heating (manqala), tannūr for bread baking, and a portable tabag mainly for baking rise bread (Ochsenschlager, 1974). In the village Kafr el-Deir in Egypt, in the 1970s, the devices included the bread oven (furn or al-qubba), a clay-built stove or an ephemeral arrangement for cooking (kānūn), and a flat metal disc for heating bread over the stove (șajja) (Rizqallah and Rizqallah, 1978: 1-8). Dalman lists four main types of built devices for bread baking in Palestine and Transjordan, along with an arrangement for cooking and baking over fire (nuqra), utensils for baking over fire or embers (zanțūs, șāj, miqlā), and metal or clay basins and boxes, which contained embers for cooking or heating the house (manqal, kānūn, mūqada, tabbāh ) (Dalman, 1928: 226-7, 1935: 39-41, 73-139, figs. 5, 12, 17, 28).

The parallel use of a small baking device and a few stones to hold a pot can be seen in Fig. 4 from Beer Sheva in the early twentieth century. A portable device might also be used in parallel with a built oven in winter or during work in the fields (Dalman, 1935: 39). In southeastern Turkey, only one type of oven was used for baking bread in the domestic sphere, the tandir, but an alternative would be "factory bread." Despite it being more labor intensive, the tandir bread was considered cheaper, tastier, more accessible, and linked to tradition (Parker and Uzel, 2007: 15).

Another point these studies highlight is the way baking technologies change over a short period of time, moving to either simpler or more complex apparatuses. In Morocco, it was the shift from a pan on the ground to an oven, whereas in Tell Mardikh in Syria the change was reversed, from ovens to a portable device. A study of bread ovens in various settlements in northern Jordan also revealed changes. Before employing gas, all cooking activities were performed in ovens, but during fieldwork these were employed only for baking. One type of oven (tannür) could still be found in bakeries, but was reported as having been out of use for twenty years (McQuitty, 1984). Notably, such changes were not observed for kilns. Even when rebuilt, the form of the kilns was maintained.

A fourth issue that comes up from additional studies is the use of communal ovens for baking in specific regions. In southeastern Turkey, in three of the four settlements that were studied, the ovens are communal and serve seven to eight families on average (Parker and Uzel, 2007: 16). A similar picture comes from eastern Turkey (Balossi Restelli, 2015: 142) and from northern Jordan (McQuitty, 1984: 265). Dalman (1935: 76)

FIGURE 4

Baking and cooking in Beer Sheva, Palestine, early twentieth century (after Dalman, 1935: fig. 26a, public domain)

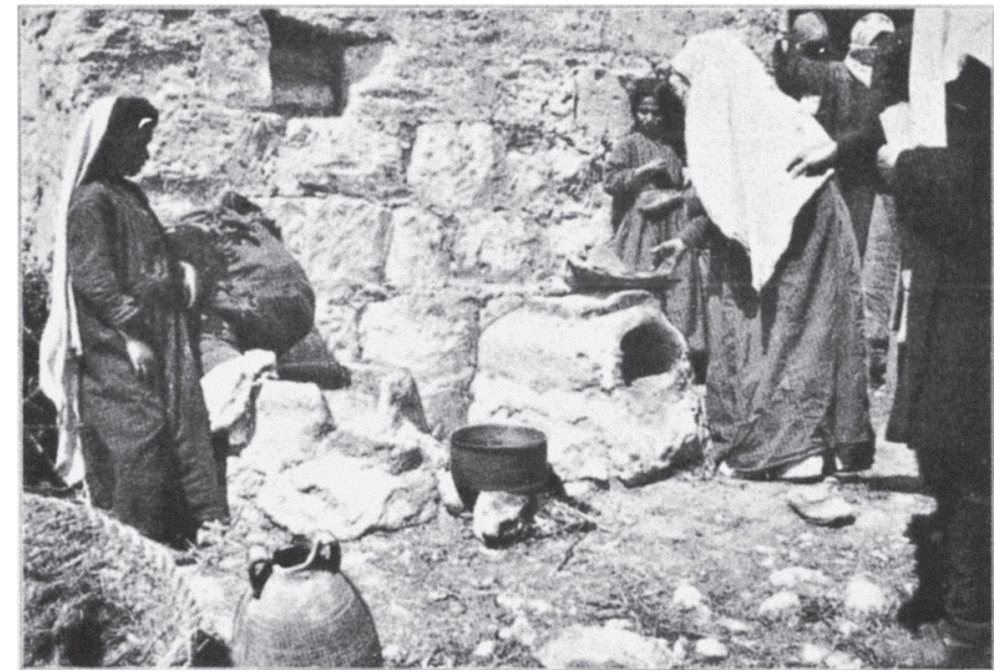

JOURNAL OF MATERIAL CULTURES IN THE MUSLIM WORLD 1 (2020) 34-66 
also notes the rotation of shared bread ovens by a number of women in Palestine. Clearly, other case studies demonstrate the private ownership of devices, such as in Syria and Morocco. Even more so, in the case study from Egypt, families would use the wide roof of their oven for sleeping in cold nights (Rizqallah and Rizqallah, 1978: 1-3).

Most relevant to our purposes are the physical residues that all fire devices leave in the short and in the long term. The example from Morocco demonstrates how all remains from fire-related activities were removed from site or were reused, so that firing and cooking cannot be recognized archaeologically. A similar result can be expected from the brass workshop in Cairo where casting facilities are natural (e.g. sand) and metal remains are immediately recycled (Shalev and Freund, 2002: 27), and from the soap factory in Jaffa (Avitsur, 1976: 265). In contrast, a pottery workshop in Deir elGharbi in Egypt left detectable traces: bowl-shaped impressions in the ground, which represented former kilns and high amounts of sherds, as $5^{-10} \%$ of the fired vessels are wasters (Nicholson and Patterson, 1985: 231, pl. 9). Still, high rates of sherds are obviously also found in the vicinity of the site, several miles away (ibid: 238). The evidence is thin, but still implies that even activities, which involve non-perishable elements, or are non-domestic, leave traces that are difficult to identify, whereas distinct remains relate to an intensive manufacture of specific products.

Fire Installations in Central Israel

The research area is a triangle on the Mediterranean coast, which lies between the modern municipalities of Tel-Aviv-Jaffa, Ashdod and Ramla in Israel. Its maximal dimensions are $41 \mathrm{~km}$ north-south, $21 \mathrm{~km}$ west-east, and $46 \mathrm{~km}$ along the shore. The archaeological research in the area is intensive, involving surveys and excavations. Until 2014, these studies recovered remains from the seventh-eleventh centuries in a total of 364 "nodes," a term that will be discussed shortly (Fig. 5). More than 120 of the nodes are in modern Ramla or neighboring Mazliah (Fig. 6). At least twenty excavations have been published as final reports and others have been published as interim reports in archaeological journals. The research area is also composed of eleven "maps"

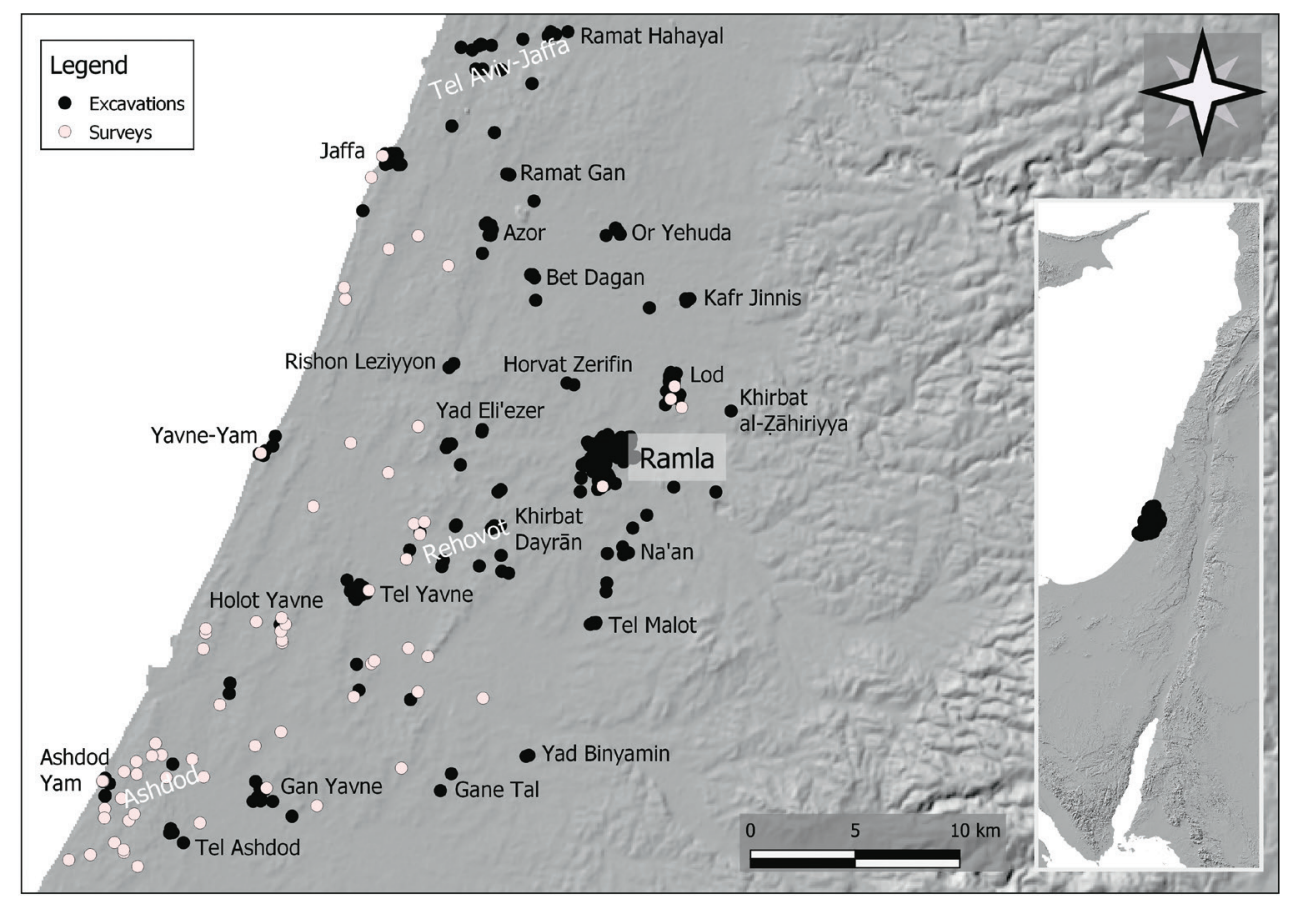

FIGURE 5

Excavated and surveyed nodes in the research area, central Israel 
FIGURE 6

Excavated nodes in Ramla and Mazliah

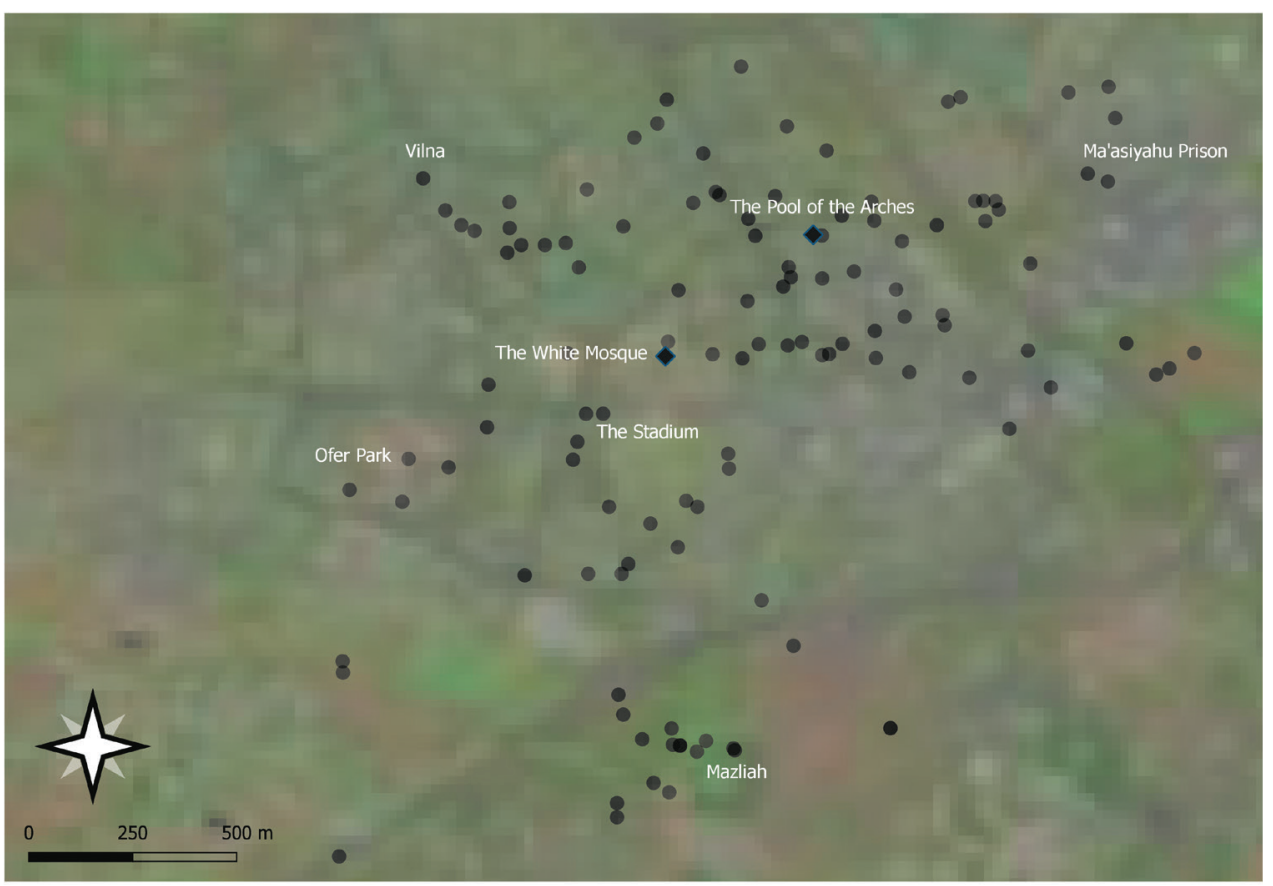

(10×10 km blocks) from the Archaeological Survey of Israel, six of which were published from 2014 onward.

The region is abundant with architecture, portable artefacts, and worked raw materials. The physical remains of fire activities comprise built installations, jars or bowls with fire remains (such as ash and charcoal), carbonized bricks, and broken and disposed clay-built (or lined) installations. In some interim reports, built fire installations are only noted, for example in most publications from Jaffa. Nevertheless, in most other publications, their measures are presented, accompanied by figures. The fire installations are preserved only partially, similarly to elsewhere (van der Steen, 1991: 137; Rova, 2014: 127), so that their maximum height, or their upper part, is unknown.

\section{1 $\quad$ Fire Installation Types}

The bulk of built installations are classified into four types. This typology is primarily based on construction methods and size, and secondarily on their correlations with related archaeological contexts. The names I gave to the types are as neutral as possible, and reflect their main characteristics in size (big, medium or small) and construction method ("built" with bricks; "lined" or built with clay). Another built FI, which seems to be associated with baths, but that was found only on three sites (Mazliah, Ashdod-Yam, and Yavne-Yam), was excluded from this study. Its interpretation is bound to developments in the bathhouse heating system and will be discussed elsewhere.

Cross-referencing the types with specific contexts or elements (e.g. the waste of crafts) might point to non-random trends, patterns of correlation, or geometric orders (Clarke, 1977: 10. See also Hodder and Hutson, 2003: 167-9o). "Archaeological context" has a dual meaning in this study. One meaning is the find's adjacent remains in its immediate surroundings, which are preferably connected to it physically (henceforth, the contextual level). The second meaning is wider, and expresses elements found at the same node as the examined find (henceforth, the node level). The term "node" is borrowed from the Network Analysis world and means small areas of archaeological investigation, such as "sites" in archaeological surveys, or limited-scale excavations. Nodes diversely comprise two to sixty excavation squares (often $5 \times 5 \mathrm{~m}$ ) and measure 
between 5 to $200 \mathrm{~m}$ in diameter. Unlike the term "site," which is a modern observation and is often imagined as a synonym for "settlement" (Thomas, 1975; Dunnell, 1992), the node is envisaged as more neutral.

A correlation between two finds on node level would mean that they come from the exact same excavation or from an adjacent node up to $100 \mathrm{~m}$ away. Correlations are not calculated statistically, as samples are small and can be observed by the naked eye. Moreover, this section presents only successful and semi-successful trends, based on wider research. The interpretation of these trends will be offered later, in order to consider all of them and the supporting evidence. Notably, the term "site" is also used in this paper, meaning a cluster of nodes that are usually found in one modern municipality or neighborhood. Following the analyses of their architecture and portable finds, I indeed interpret these sites as settlements.

Archaeological contexts from node perspective or node-cluster perspective allow for the identification of links between a number of installations or specific activities that are practiced at some distance from each other. Likewise, it bypasses interpretation challenges, which relate to Schiffer's "cultural formation processes," such as emptying installations and disposing refuse (or recycling it) in another location. While patterns I observe can be random, their repetition or supplementation implies a realistic trend. The validity of the trend can be supported by external evidence.

The first type is the Big-Built fire installation (в в) that is often called a "kiln" in literature. It is dug, round or oval, $2-3 \mathrm{~m}$ in internal diameter (or larger), and frequently built of mud-bricks. The type may have an internal pillar or a pilaster, which likely carried a second floor (Fig. 7, nodes: 108, 140, 291 and 351). Two installations of a similar type were unearthed in Aqaba, Jordan, $250 \mathrm{~m}$ north of the fortified site of Ayla (Melkawi et al., 1994). In the research area, this type can be found surrounded by pottery waste, including ash and deformed vessels (nodes 132 and 265) or only adjacent to such waste contexts (nodes 108, 134 and 140). On the node level, the only correlation is that nine out of fourteen nodes also contain refuse (Table 3 ), but that is not much of a contribution.

The second type is the Medium-Lined F I (ML). It is round, $1-1.5 \mathrm{~m}$ in internal diameter, made of mud, and partly dug. It is defined in literature diversely as a "kiln," a tabūn

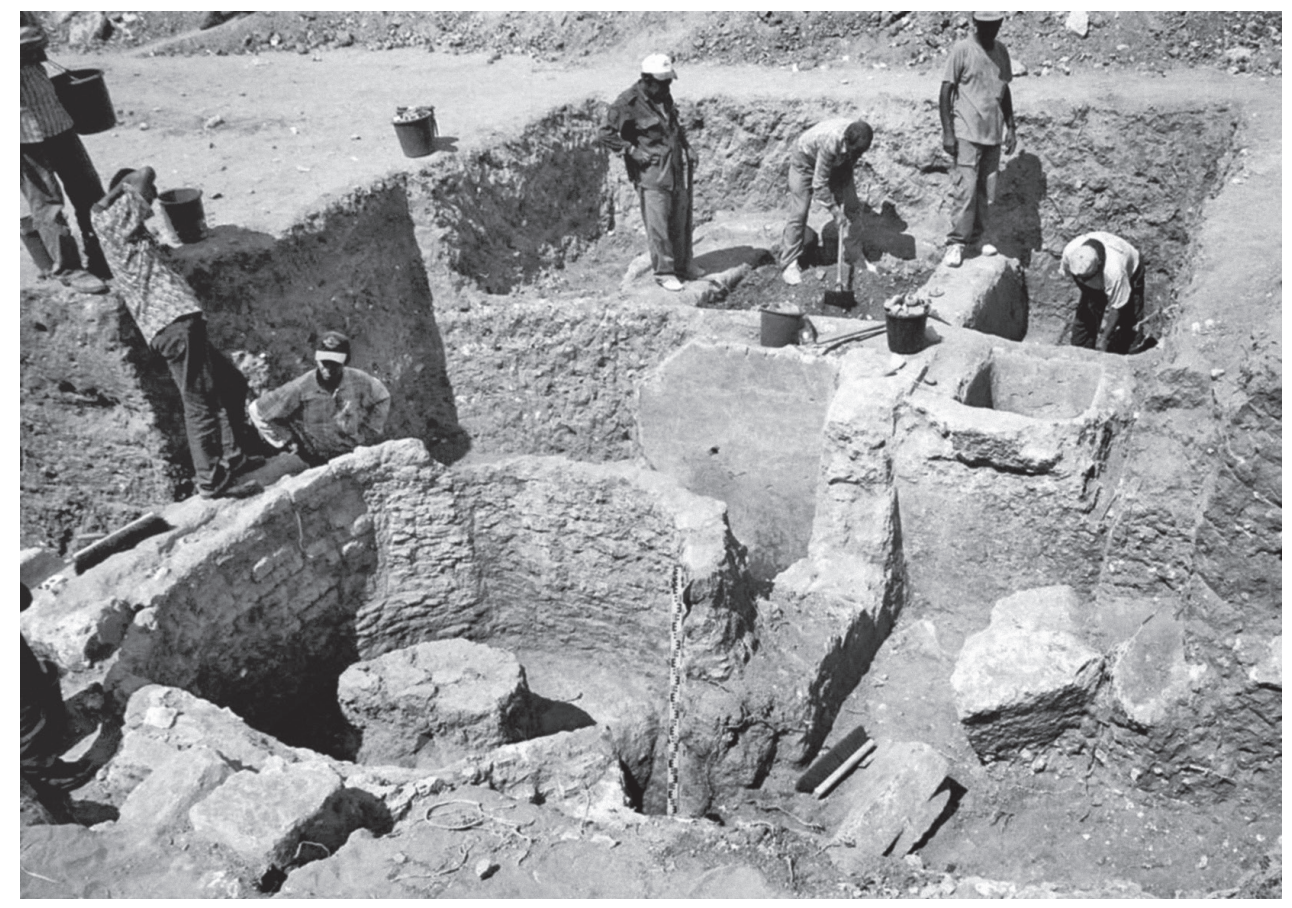

FIGURE 7

Big-Built fire installation from Na'an

COURTESY OF GIL TSIONI, THE UNIVERSITY OF HAIFA 
TABLE 3

Correlations on the node level of Big-Built fire installations
FIGURE 8

Medium-Lined fire installation from Khirbat Dayrān, Rehovot PHOTO: TSILA SAGIV, COURTESY OF THE ISRAEL ANTIQUITIES AUTHORITY

$\begin{array}{llll}\text { Site } & \text { Node } & \begin{array}{l}\text { Node/area size } \\ \text { (in diameter) }\end{array} & \begin{array}{l}\text { Certain } \\ \text { type }\end{array}\end{array}$ Refuse Bib

\begin{tabular}{|c|c|c|c|c|c|}
\hline Ramla & 67 & 200 & & & Avni et al. (2008) \\
\hline Ramla & 93 & $\sim 40$ & & & Shor (1999) \\
\hline Na'an & 108 & 35 & yes & yes & $\begin{array}{l}\text { Tsioni (2008): section II, } \\
39-44 \text {, photos } 4-7 \text {, fig. } 7\end{array}$ \\
\hline Mazliah & 132 & $5^{\circ}$ & yes & yes & Gorzalczany (2006): area B \\
\hline Mazliah & 137 & $\sim 100$ & & yes & Tal and Taxel (2008): 63 \\
\hline Mazliah & 140 & & yes & yes & Gorzalczany (2009) \\
\hline Or Yehuda & 181 & 70 & yes & & $\begin{array}{l}\text { Barkan and Jakoel (2010): } \\
\text { areas B, C }\end{array}$ \\
\hline Ramat Gan & 186 & 15 & yes & yes & 'Ad (200o) \\
\hline Tell Qasile & 206 & & & & $\begin{array}{l}\text { Bar-Nathan (2002): 131, } \\
\text { A-61o/76, A-1006/81-01 }\end{array}$ \\
\hline Hadar Yosef & 207 & & & yes & $\begin{array}{l}\text { Bar-Nathan (2002): 131, } \\
\text { A-230/70 }\end{array}$ \\
\hline Jaffa & 253 & $\sim 140$ & & & Peilstöcker (1998) \\
\hline Tel Yavne & 265 & 110 & yes & yes & Yannai (2014): area C \\
\hline Horvat Hermas & 291 & 120 & yes & yes & Elisha $(2007)$ \\
\hline Gan Yavne & 345 & $\sim 70$ & yes & yes & Gadot and Tepper (2003) \\
\hline Total 14 & & & 8 & 9 & \\
\hline
\end{tabular}

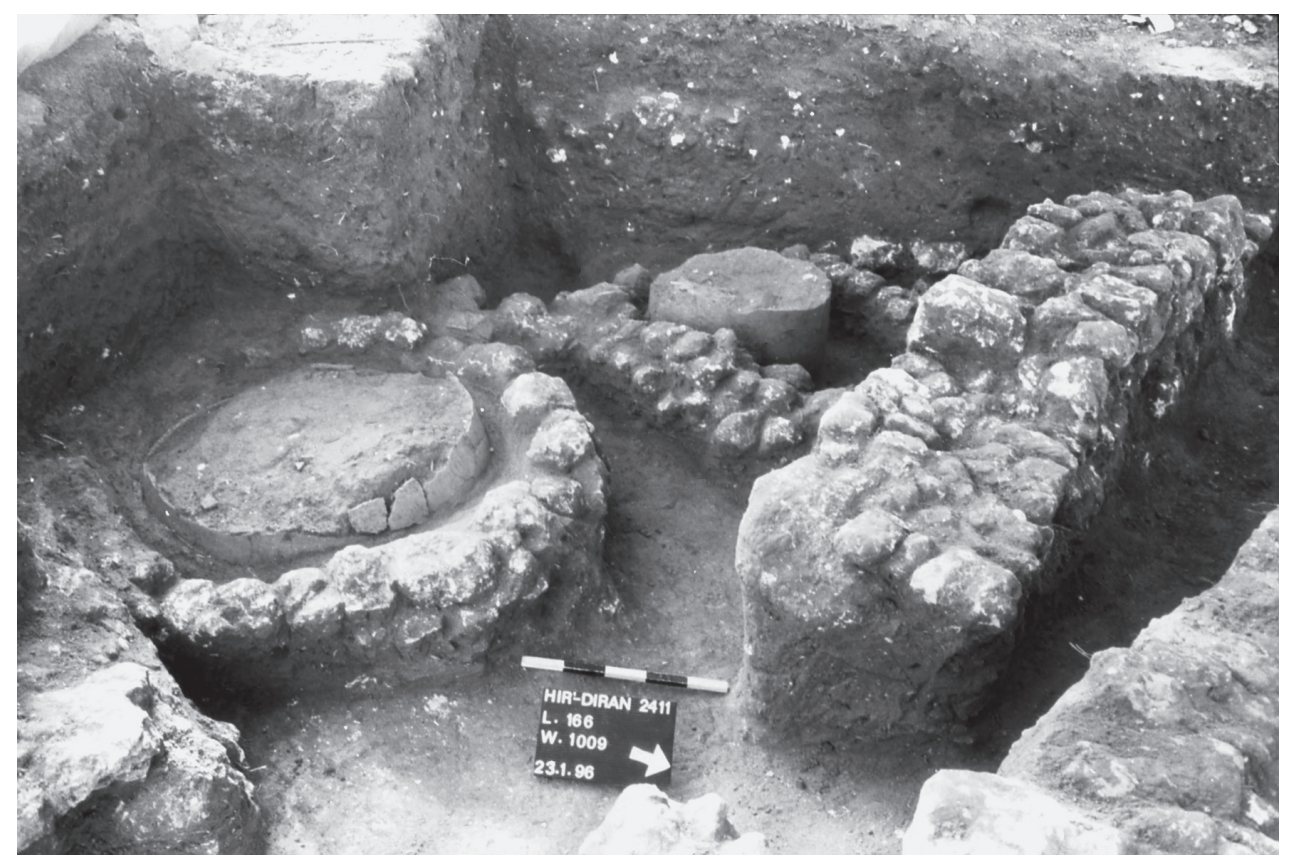

or an oven. In Khirbat Dayrān in Rehovot, this type has an additional side air-tube made of two or three long jars, which cannot be seen in the picture (Fig. 8), but in its restoration (Bouchenino, 2007: 122; Kogan-Zehavi, 20o8: 83, figs. 6-7). In Tel Yavne, scholars consider this type to be a glass kiln (Fig. 9) (Feldstein and Shmueli, 2011: figs. 3-4.). In Nishapur, Iran, a similar installation was unearthed from many of the rooms, with a broken jar at the bottom of the installation and a channel of several other jars. The excavators interpreted that installation as a brazier that was also used as a grill or a heater 


\begin{tabular}{|c|c|c|c|c|c|c|c|c|c|}
\hline \multirow[t]{2}{*}{ Site } & \multirow[t]{2}{*}{ Node } & \multirow{2}{*}{$\begin{array}{l}\text { Node } \\
\text { size }\end{array}$} & \multicolumn{2}{|c|}{ Details } & \multicolumn{3}{|c|}{ Correlations } & \multirow[b]{2}{*}{ Conduits } & \multirow[t]{2}{*}{ Bib } \\
\hline & & & $\begin{array}{l}\text { Certain } \\
\text { type }\end{array}$ & Vent & Waste & Structures & Fieldstone & & \\
\hline Ramla & 17 & 5 & & & & & & yes & $\begin{array}{l}\text { Masarwa } \\
(2011)\end{array}$ \\
\hline Mazliah & 134 & $\sim 80$ & yes & & $\begin{array}{l}\text { pottery, } \\
\text { glass }\end{array}$ & yes & yes & yes & $\begin{array}{l}\text { Gorzalczany } \\
\text { et al. (2010) }\end{array}$ \\
\hline Azor & 166 & $\sim 16$ o & yes & & & yes & yes & yes & $\begin{array}{l}\text { 'Ad et al. } \\
(2014)\end{array}$ \\
\hline Azor & 178 & 30 & (also SL) & & $\begin{array}{l}\text { glass } \\
\text { (slag) }\end{array}$ & yes & yes & & $\begin{array}{l}\text { Torgë } \\
(2005 a)\end{array}$ \\
\hline $\begin{array}{l}\text { Yad } \\
\text { Eli'ezer }\end{array}$ & 216 & 30 & & & $\begin{array}{l}\text { glass } \\
\text { (slag) }\end{array}$ & yes & & & $\begin{array}{l}\text { Gorzalczany } \\
(2004)\end{array}$ \\
\hline Tel Yavne & 274 & 65 & yes & yes & $\begin{array}{l}\text { glass } \\
\text { (slag) }\end{array}$ & (installation) & & yes & $\begin{array}{l}\text { Feldstein } \\
\text { and Shmueli } \\
(2011)\end{array}$ \\
\hline $\begin{array}{l}\text { Weizmann } \\
\text { Institute }\end{array}$ & 276 & 5 & & yes & pottery & yes & yes & & $\begin{array}{l}\text { Ovadia } \\
(1962)\end{array}$ \\
\hline $\begin{array}{l}\text { Khirbat } \\
\text { Dayrān }\end{array}$ & 283 & 30 & & yes & & yes & yes & yes & $\begin{array}{l}\text { Bouchenino } \\
(2007)\end{array}$ \\
\hline $\begin{array}{l}\text { Khirbat } \\
\text { Dayrān }\end{array}$ & 284 & 5 & yes & yes & & yes & yes & yes & $\begin{array}{l}\text { Kogan- } \\
\text { Zehavi } \\
(2008)\end{array}$ \\
\hline $\begin{array}{l}\text { Horvat } \\
\text { Hermas }\end{array}$ & 291 & 120 & $\begin{array}{l}\text { (also } \\
\text { вв) }\end{array}$ & & $\begin{array}{l}\text { pottery, } \\
\text { glass }\end{array}$ & yes & (installation) & & $\begin{array}{l}\text { Elisha } \\
(2007)\end{array}$ \\
\hline $\begin{array}{l}\text { Kefar } \\
\text { Gabirol }\end{array}$ & 292 & 40 & yes & & & yes & yes & & $\begin{array}{l}\text { Volynsky } \\
\text { and Talmi } \\
(2011) \text { : } \\
\text { area P }\end{array}$ \\
\hline Ganne Tal & 300 & 110 & $\begin{array}{l}\text { (also } \\
\mathrm{SL} \text { ) }\end{array}$ & yes & glass & yes & yes & yes & $\begin{array}{l}\text { Arbel } \\
(2011) \text { : areas } \\
\text { D1, D2 }\end{array}$ \\
\hline Tel Ashdod & 351 & & & & pottery & yes & yes & yes & $\begin{array}{l}\text { Dothan } \\
\text { and Porath } \\
(1982): 44-5\end{array}$ \\
\hline Total 12 & & & & 5 & 8 & 11 & 10 & 8 & \\
\hline
\end{tabular}

(Wikinson, 1986: 224-5, figs. 3.8, 3.9). In the research area, eleven/twelve of the thirteen nodes of that type have structures (with a clear preference for fieldstone) and/or conduits (eight nodes). In addition, six nodes contain glass-production remains, mainly slag, and four pottery waste (Table 4).

The Small-Lined (SL) FI is known in archaeological literature as tabūn. Through analogies to modern communities, scholars often associate it with domestic baking (Ebeling and Rogel, 2015). Similar to the former type, it is rounded and made of mud. In contrast, it was not dug, but built on the ground, its internal diameter is $0.4-0.8 \mathrm{~m}$, and its remains vary between 0.3 and $1 \mathrm{~m}$ in height. A contextual examination of this type shows that it is almost always adjacent to walls (Fig. 10, nodes 15, 141, 148, 162, 176, 284, 300 ), sometimes in a corner (nodes 46,213 ).
TABLE 4

Correlations on the node level of Medium-Lined fire installations

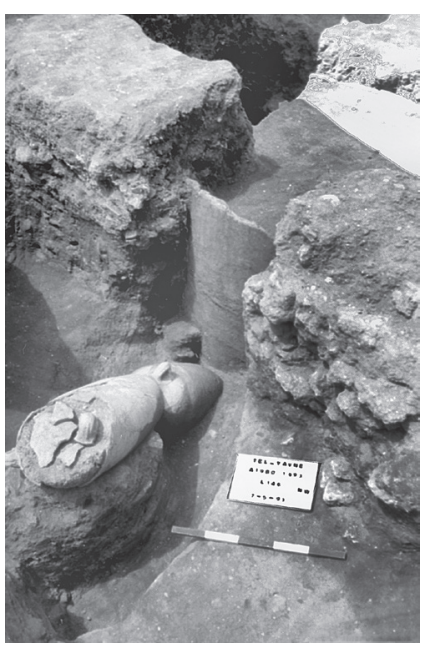

FIGURE 9

Medium-Lined fire installation from Tel Yavne

PHOTO: AMIR FELDSTEIN, COURTESY OF THE ISRAEL ANTIQUITIES AUTHORITY

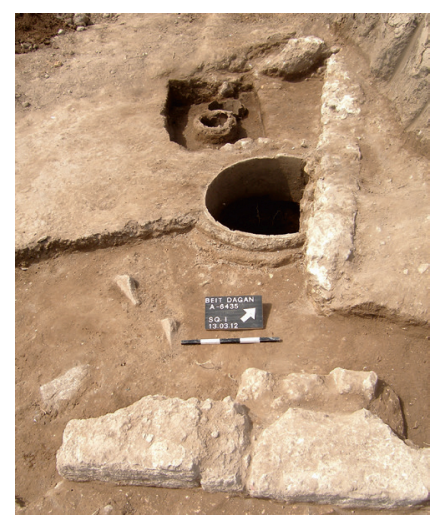

FIGURE 10

Small-Lined Fire installation and two jars from Bet Dagan PHOTO: AMIR GORZALCZANY, COURTESY OF THE ISRAEL ANTIQQUITIES AUTHORITY 
TABLE 5

Small-Lined FI type 1 and the characteristics of its nodes

\begin{tabular}{|c|c|c|c|c|c|c|c|c|c|c|}
\hline Site & Node & $\begin{array}{l}\text { Node } \\
\text { size }\end{array}$ & $\begin{array}{l}\text { Certain } \\
\text { type }\end{array}$ & Waste & Refuse & Walls & Conduits & Bones & Copper & $\mathrm{Bib}$ \\
\hline Ramla & 15 & 25 & yes & & & yes & & & yes & Jakoel (2011) \\
\hline Ramla & 26 & 30 & & & & yes & yes & & & Torgë (2011) \\
\hline Ramla & 46 & 10 & yes & & & yes & yes & & & $\begin{array}{l}\text { Gudovitch } \\
(2004)\end{array}$ \\
\hline Na'an & 109 & 100 & yes & pottery & & & yes & yes & & $\begin{array}{l}\text { Torgë }(2010) \text { : } \\
\text { areas C and } \\
\text { D }\end{array}$ \\
\hline Kafr Jinnis & 123 & 25 & & & dug pit & yes & & & yes & $\begin{array}{l}\text { Messika } \\
(2006) \text { : area } \\
\text { C, } 89\end{array}$ \\
\hline Mazliah & 141 & $15^{\circ}$ & yes & & yes & & yes & & yes & $\begin{array}{l}\text { Gorzalczany } \\
\text { and Spivak } \\
(2008)\end{array}$ \\
\hline Bet Dagan & 162 & 40 & yes & & & yes & & yes & & $\begin{array}{l}\text { Gorzalczany } \\
\text { and Jakoel } \\
(2013)\end{array}$ \\
\hline Azor & 166 & $\sim 15^{\circ}$ & yes & & & yes & yes & & & $\begin{array}{l}\text { 'Ad et al. } \\
(2014)\end{array}$ \\
\hline $\begin{array}{l}\text { Ramat } \\
\text { Gan }\end{array}$ & 184 & 30 & yes & & & yes & & & yes & $\begin{array}{l}\text { Volynsky } \\
\text { (2009) }\end{array}$ \\
\hline $\begin{array}{l}\text { Tell } \\
\text { Qasile }\end{array}$ & 208 & 4 & $\begin{array}{l}\text { (not in } \\
\text { situ) }\end{array}$ & $\begin{array}{l}\text { metal } \\
\text { slag }\end{array}$ & & & yes & yes & & $\begin{array}{l}\text { Ayalon and } \\
\text { Bashkin- } \\
\text { Yosef (2008) }\end{array}$ \\
\hline H. Zerifin & 213 & 30 & yes & & yes & yes & yes & yes & & $\begin{array}{l}\text { Govrin } \\
(2013) \text { : } \\
\text { area A }\end{array}$ \\
\hline Jaffa & 257 & $5^{\circ}$ & & & & & & & & $\begin{array}{l}\text { Peilstöcker } \\
\text { et al. (2006) }\end{array}$ \\
\hline $\begin{array}{l}\text { Yad } \\
\text { Binyamin }\end{array}$ & 302 & 20 & & & & & & & & $\begin{array}{l}\text { Weksler- } \\
\text { Bdolah } \\
(2000)\end{array}$ \\
\hline $\begin{array}{l}\text { Ashdod- } \\
\text { Yam }^{\mathrm{a}}\end{array}$ & 319 & $\sim 70$ & & & & yes & yes & yes & yes & \\
\hline Total 14 & & & & 2 & 3 & 9 & 8 & 5 & 5 & \\
\hline
\end{tabular}

a Israel Antiquities Authority Archives: Excavation Files: Ashdod-Yam, Yosef Porath and Shlomo Pipano, A-1353/1985 (Area B, L826).

Two reverse patterns on the node level divide the Small-Lined FI into two sub-types (Tables 5 and 6). Small-Lined fire installation type 1 (SL1) is related to structures and conduits, as well as to portable finds: animal bones and copper-alloy objects. It is rarely related to industrial waste or to other refuse. Interestingly, it appears in most sites, but usually only in one node (except for Ramla/Mazliah with four nodes). Small-Lined F I type 2 (SL2) is distinctly different. On the one hand, its nodes have almost no conduits, no animal bones, and no metals. On the other hand, in half of the nodes, the installation is found in a complex of several adjacent fire installations of the same type. In six of the nodes there is a designated refuse pit (which is not common), and in three, the remains of glass production have been found. 
Site Node Node Certain Waste Refuse Walls Conduits Bones Copper Bib size type

\begin{tabular}{|c|c|c|c|c|c|c|c|c|c|c|}
\hline Ramla & 12 & 20 & yes (3) & & & & & & & $\begin{array}{l}\text { Kanias and } \\
\text { Tueg (2012) }\end{array}$ \\
\hline Na'an & 108 & 60 & yes (4) & glass & & yes & & & & $\begin{array}{l}\text { Tsioni } \\
(2008) \text { : sec- } \\
\text { tion IV, } 45^{-7}\end{array}$ \\
\hline Lod & 144 & $\sim 10$ & yes & & dug pit & yes & & & & Torgë (2003) \\
\hline Lod & 148 & 10 & yes & & dug pit & yes & & & & $\begin{array}{l}\text { Golani } \\
(2012)\end{array}$ \\
\hline $\begin{array}{l}\text { Bet } \\
\text { Dagan }\end{array}$ & 163 & & yes & & dug pit & yes & yes & & & $\begin{array}{l}\text { Peilstöcker } \\
\text { and } \\
\text { Kapitikon } \\
(1998)\end{array}$ \\
\hline Azor & 167 & 20 & yes & & dug pit & yes & & & & $\begin{array}{l}\text { Dagot } \\
(2014)\end{array}$ \\
\hline Azor & 176 & 12 & yes (2) & & dug pit & yes & & & & $\begin{array}{l}\text { Rauchberger } \\
\text { (2009) }\end{array}$ \\
\hline Azor & 178 & 30 & $\begin{array}{l}\text { yes (4), } \\
\text { also ML }\end{array}$ & $\begin{array}{l}\text { glass } \\
\text { slag }\end{array}$ & $\begin{array}{l}\text { dug } \\
\text { pit? }\end{array}$ & yes & & & & $\begin{array}{l}\text { Torgë } \\
(2005 a)\end{array}$ \\
\hline $\begin{array}{l}\text { Ganne } \\
\text { Tal }\end{array}$ & 300 & 110 & $\begin{array}{l}\text { yes (4), } \\
\text { also ML }\end{array}$ & glass & & yes & yes & & & Arbel (2011) \\
\hline Total 9 & & & $\begin{array}{l}5 \\
\text { multiple }\end{array}$ & 3 & 6 & 7 & 2 & o & o & \\
\hline
\end{tabular}

\subsection{Spatial Patterns of Fire Installations}

The distribution of three fire installations types shows a clear geographical division (Fig. 11). The SL1 installations dominate the eastern side of the research area, whereas $\mathrm{ML}$ is distributed from Azor to the south with a concentration on the sites of Rehovot, and вв forms a northern cluster and another cluster near Ramla. This could mean a geographical division either of the construction technique of FI, or of their function.

In order to examine if FI types can be associated with specific industries, they are cross-referenced with the waste and raw materials of crafts. In the research area, remains of pottery production include deformed vessels and molds; remains of secondary glass production include deformed vessels, molds, and glass chunks; and remains of metal smelting include slag or raw metals. Cross-referencing glass waste with Medium-Lined FI resulted in a clear relation, with only a few exceptions (Fig. 12). Cross-referencing pottery waste with Big-Built FI resulted in a less distinct relation, with exceptions on the northern part of the map and around Ramla (Fig. 13).

Metal waste is too limited for any observation. Some correlation was found between Small-Lined Fi type 1 and a copper-alloy object with a lollipop form (Fig. 14). The copper "lollipops" (Fig. 15) are found in most big excavations of Greater Syria and appear in museum collections. The object has elicited diverse interpretations, starting with a cosmetic mortar, an indigo crucible, a lamp, or a lamp-filler (e.g. Grabar et al., 1978: 183, 282-3, figs. 39-40; Allan, 1982: 37-8; Whitcomb, 1988: fig. 25:c; Messika, 2006: 105, fig. 23:6). I believe it to be a mortar of some sort, for cosmetics and/or medicine.
TABLE 6

Small-Lined Fi type 2 and the characteristics of its nodes 
FIGURE 11

The dispersion of fire installations in the research area
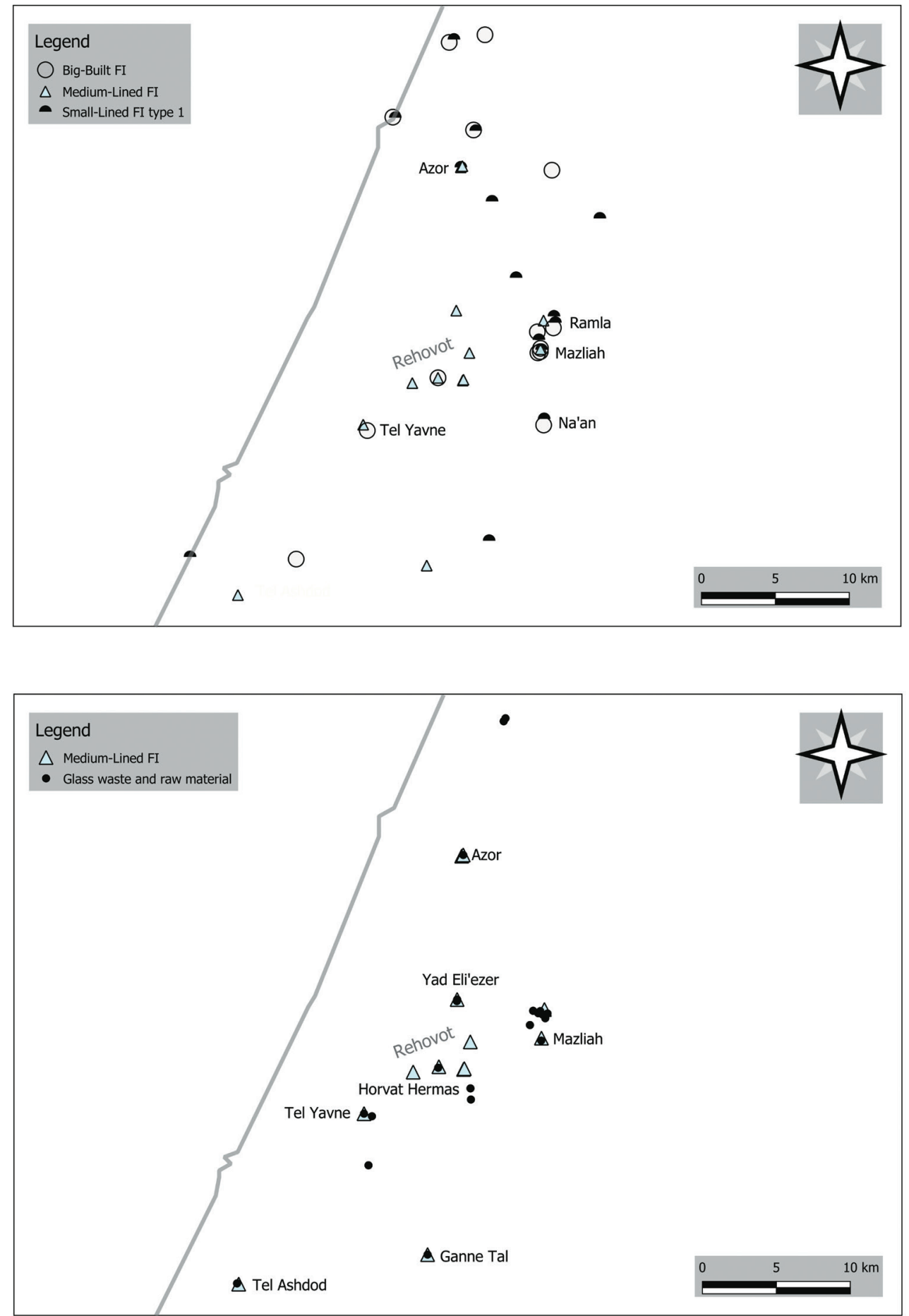

An interesting pattern emerges when looking at the distribution of fire remains within sites. Five sites with sufficient numbers of salvage excavations were investigated (Jaffa, Azor, Lod, Tel Yavne, and Gan Yavne). On each site, the four types of fire installations were mapped in relation to all relevant excavated nodes of the site (Fig. 16). Except for Azor that had a big number of fire installation and three types, these sites had one or two types of installations, and only in very few nodes. Notably, the installations in Lod, Gan Yavne and Tel Yavne were clearly situated on the edge of the site.

The location of fire remains inside Ramla can be mapped and compared to Ramla's established "activity areas." Many installations, together with some other elements, 

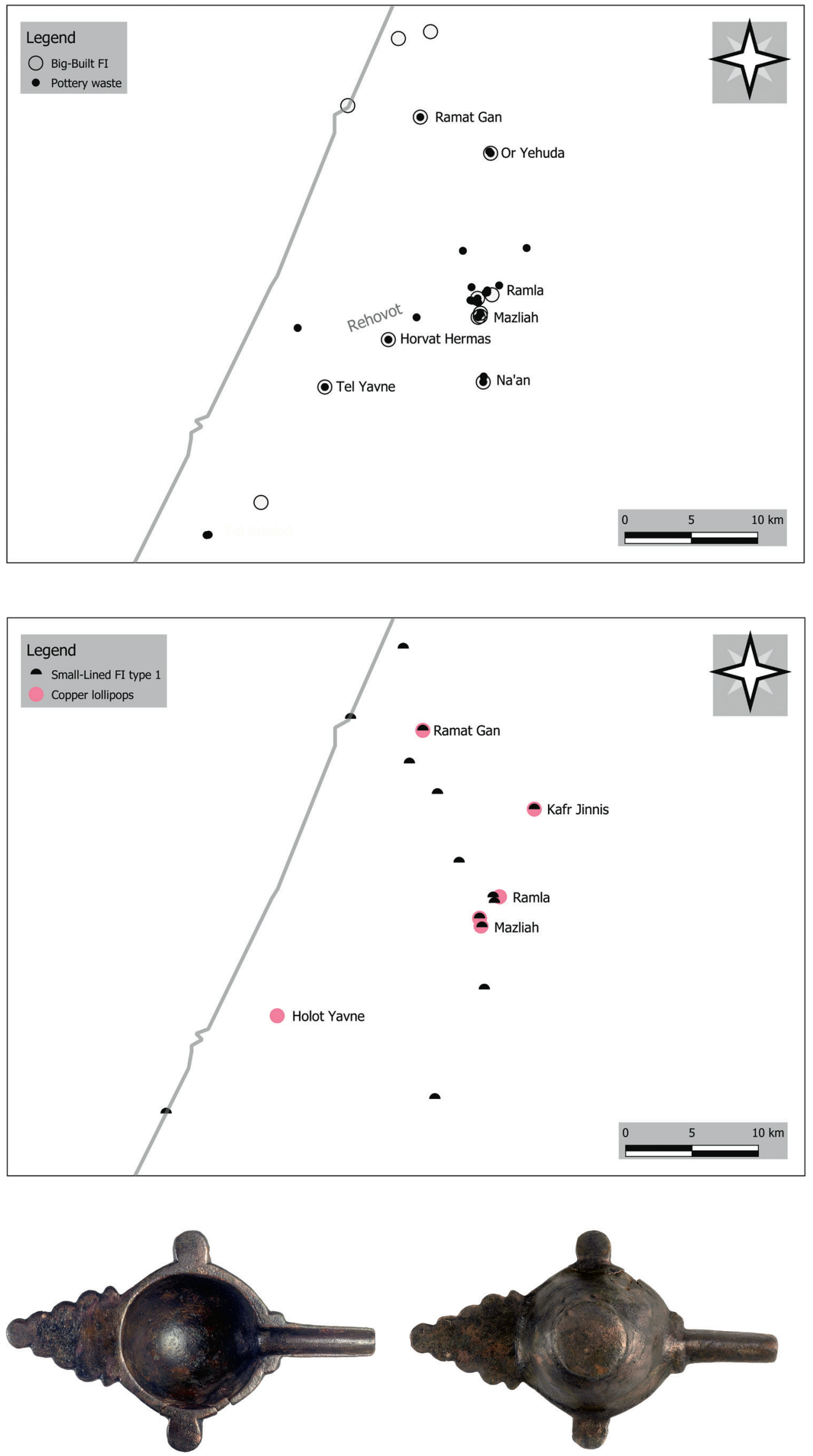

${ }_{0}^{|||||||||||||||||||||||||||||||||||||||||||||||||||||||||||||||||||||||||||||||||||||||||| \mid}$
A-4571 1080

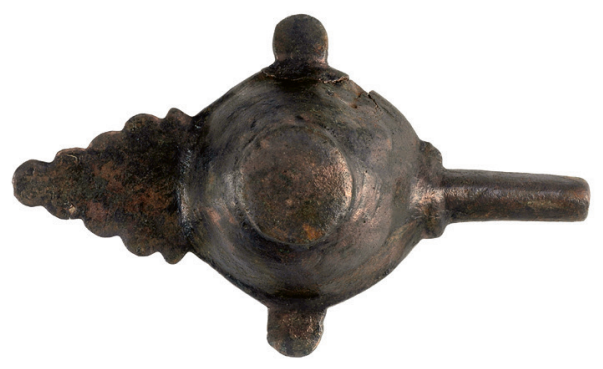

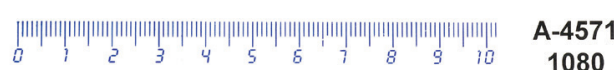

FIGURE 13

Cross-referencing pottery waste with Big-Built F I

FIGURE 14

Cross-referencing lollipop-form objects with Small-Lined FI type 1

FIGURE 15

A lollipop-form object from Ramat Gan PHOTO: CLARA AMIT, COURTESY OF THE ISRAEL ANTIQUITIES AUTHORITY 
FIGURE 16

Fire installations and fire remains within five sites
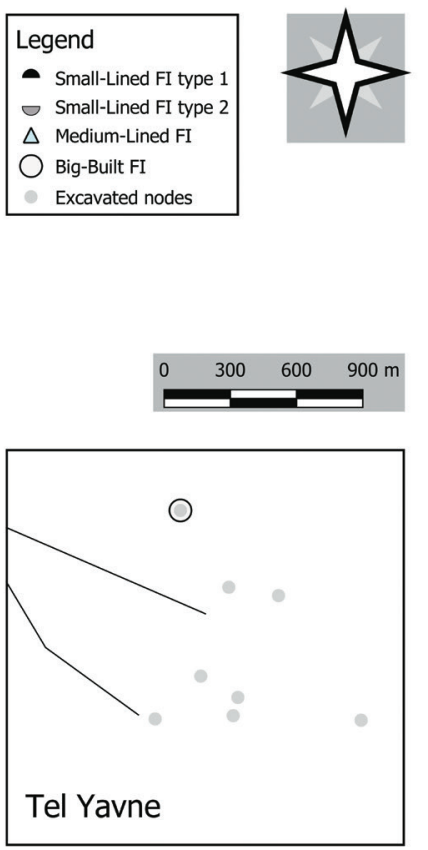
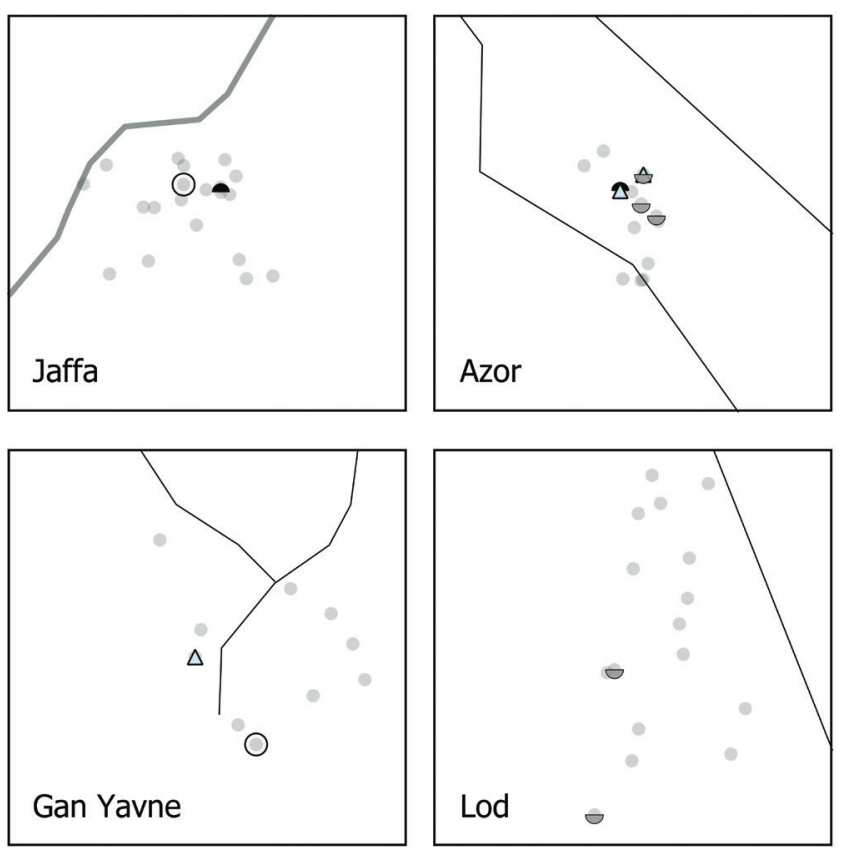

correlated with specific areas within the modern domain. Furthermore, territories of specific elements were distinct from others (Nol, forthcoming). The first type of activity area is three clusters of flagstone pavements which also comprise Medium-Lined or Big-Built fire installations and a floorless installation with a barrel-shaped vault. A comparison to Caesarea and Acre, where similar structures (albeit not subterranean) were paved with mosaics or flagstones (Avni, 2014: 51), suggests their interpretation as warehouses. The rich terminology for storage rooms from that period, and specifically for subterranean spaces (i.e. madāfin, Specubus subterraneis), supports that interpretation. Two of these three clusters are also characterized by the presence of objects made of iron, by vessels made of soapstone, and by clay "grenades" (sphero-conical vessels).

A second type of activity area in Ramla that is situated in different territories than the former, consists of bell-shape plastered containers along with in situ sunken jars. The bell-containers, many approached by clay pipes, are suggested to collect drinking water from floors and roofs, whereas sunken jars may relate to storage. The third type of activity area is found on the site's edges or within the flagstone pavements. It is characterized by designated refuse pits along with rotary querns made of basalt and with marble basins. I interpret these three activity areas as industrial, domestic, and refuse related (Fig. 17). Henceforth, the flagstone pavement is interpreted as a public space, an industrial area, or an industrial market.

A comparison between fire installations and dwelling areas in Ramla (Fig. 18) shows some correlation with hearths and with Small-Lined FI type 1. One Big-Built FI is also found in the dwelling neighborhood. Otherwise, в в can be found in the industrial areas of Mazliah and the Stadium (Fig. 19). The latter map also illustrates the position of hearths and ML in or around the industrial areas. Regarding specific crafts at Ramla, a good correlation can be noticed for pottery waste with в в or with hearths, especially in the industrial areas (Fig. 20). Very different, but also distinct, is the wide distribution of glass-production remains in one cluster outside any of the activity areas, and with no distinct relation to any particular FI (Fig. 21). 

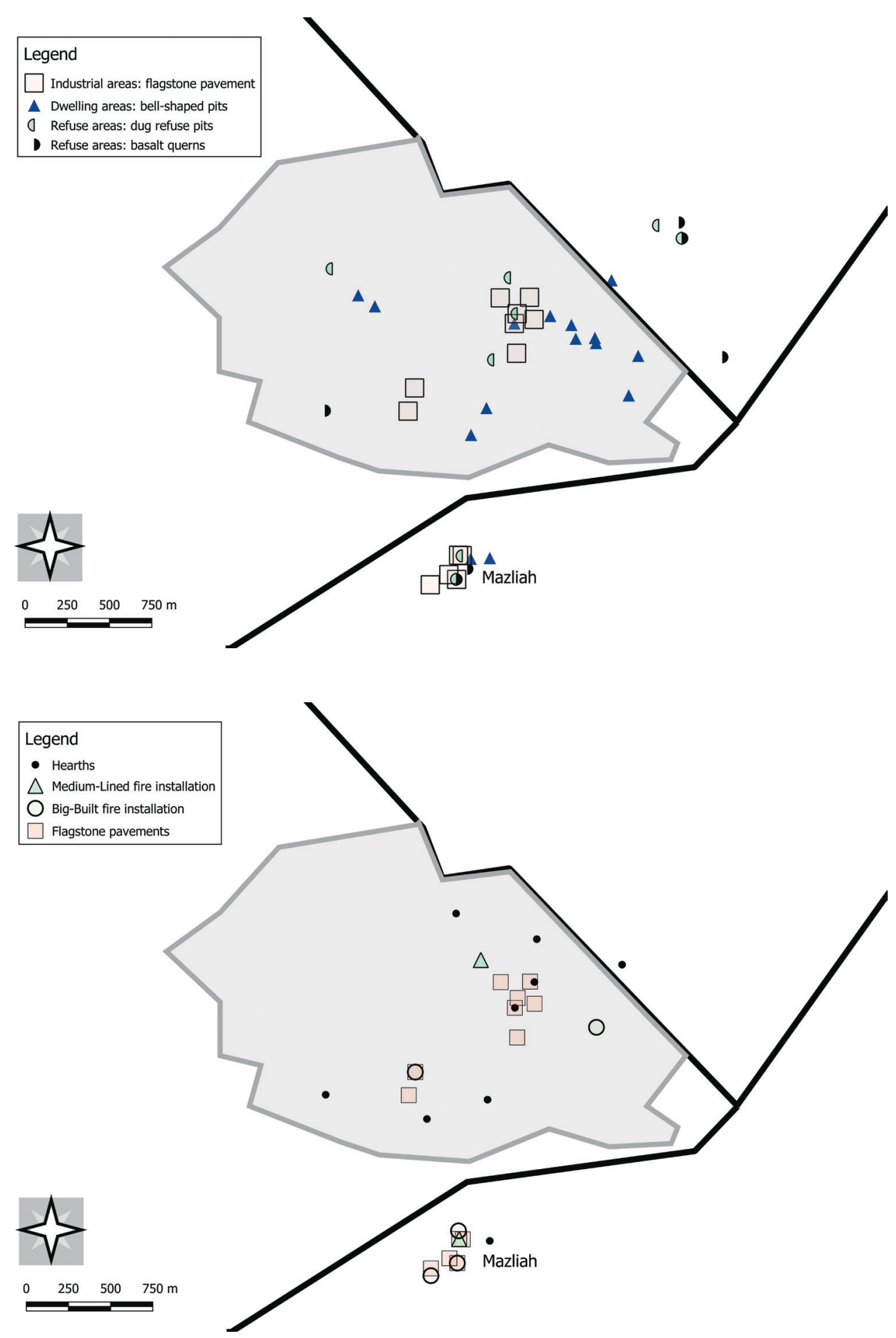

6

Discussion: Interpreting the Fire Installations and Related Activities

Preferring one fire installation over another relates to function and geography, though not exclusively. The best example is the Medium-Lined fire installations which are concentrated in Rehovot and its vicinity. In fact, the Yarqon area was excluded of this type altogether. The spatial distribution on the node level shows the possible link between this type and glass production, with examples from Ganne Tal, Tel Ashdod and Azor, in
FIGURE 17

A summary of activity areas in Ramla

FIGURE 18

Fire installations in the dwelling areas of Ramla 
FIGURE 19

Fire installations in the industrial areas of Ramla
FIGURE 20

Cross-referencing fire installations and pottery waste at Ramla
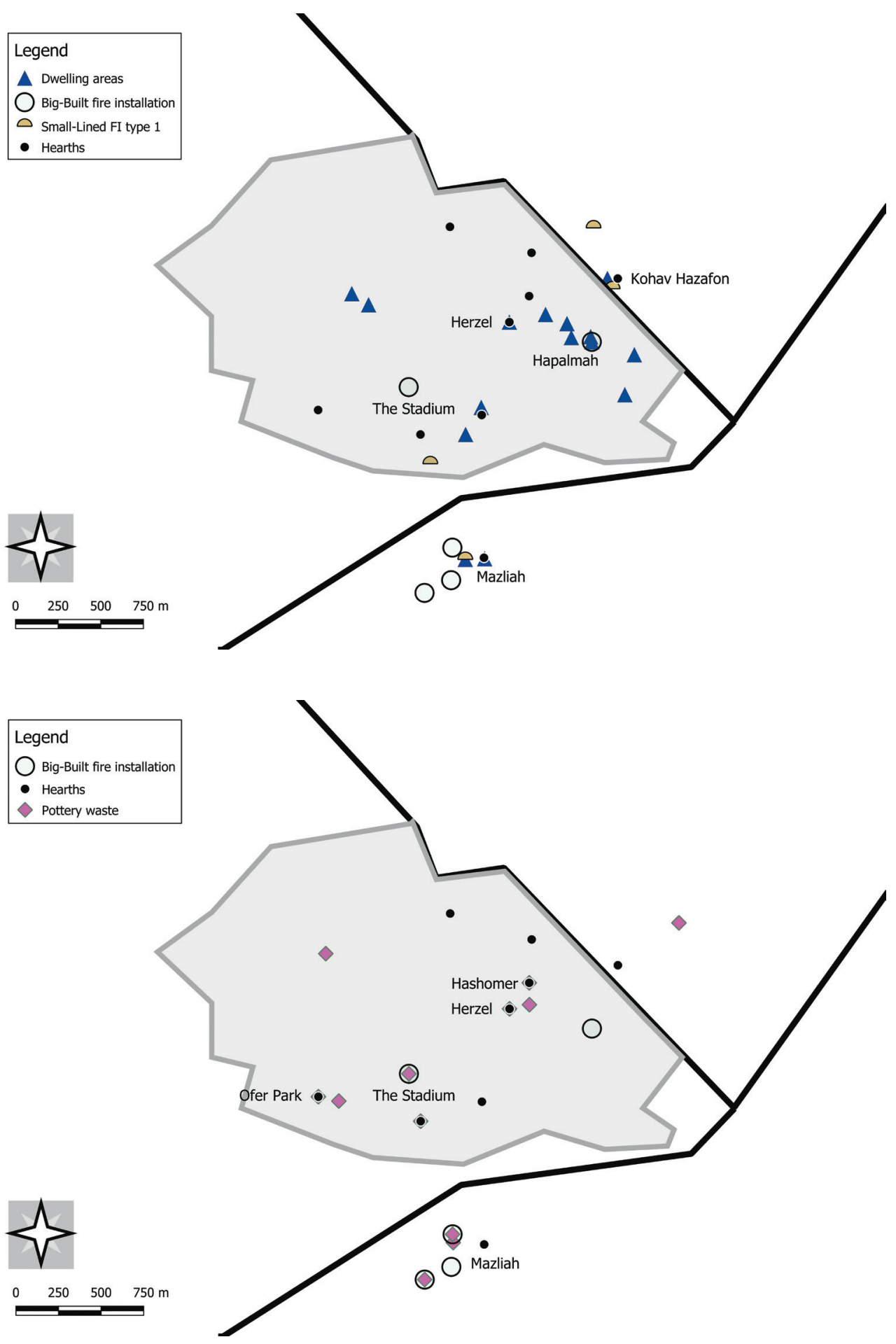

addition to the Rehovot cluster. However, in the Rehovot cluster, sites were alternatively found only with waste of another craft, such as pottery (e.g. Weizmann Institute) or metal (e.g. Khirbat Dayrān). In Ramla, ML is the best candidate for glass production, as the widespread distribution of glass remains is in its proximity. In summary, I support the suggestion made by Feldstein and Shmueli (2011) to interpret this type as a glass kiln. However, on the Rehovot sites, where it was the sole type of fire installation, it might have had multiple uses. 


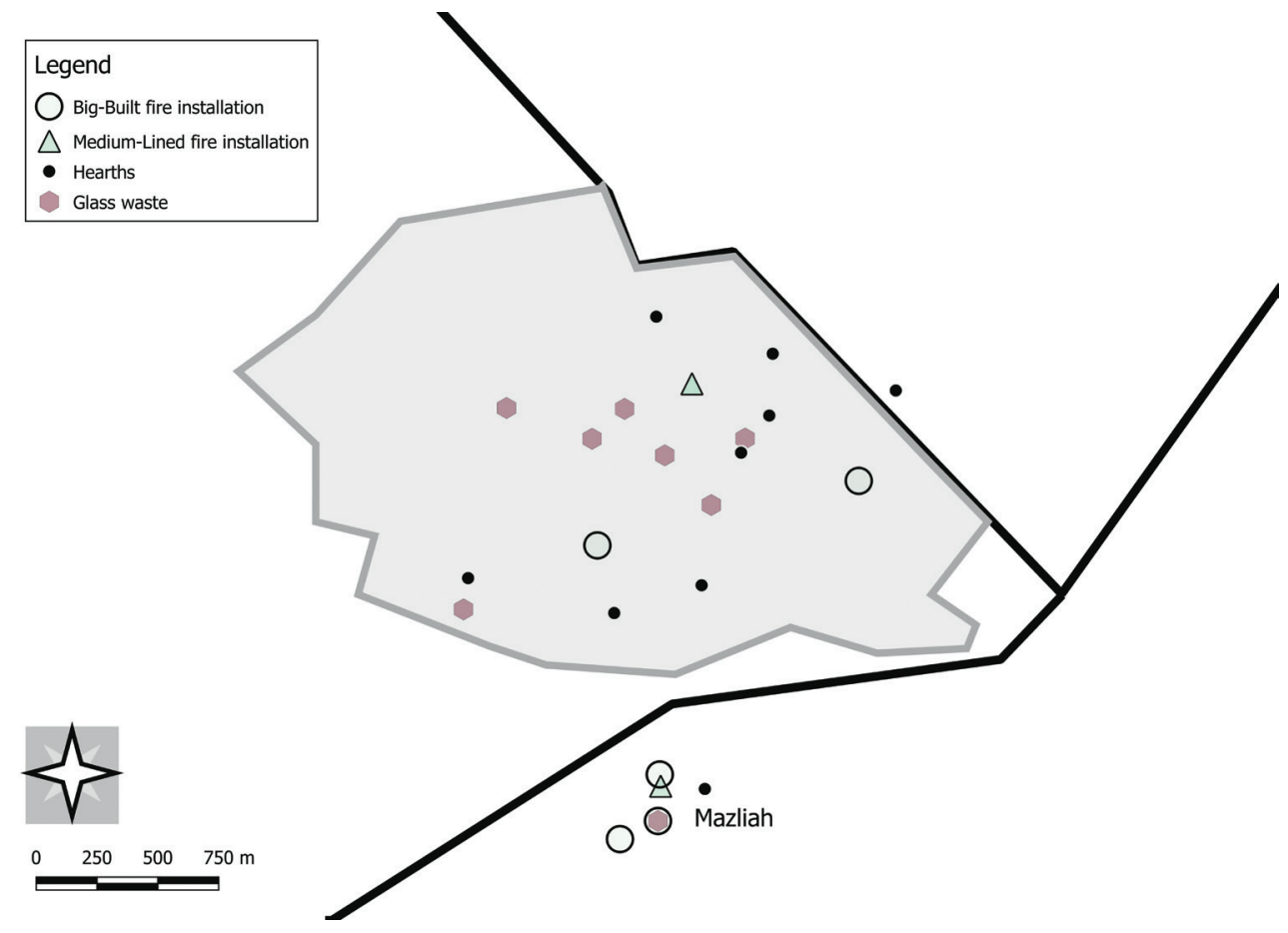

Big-Built fire installations and pottery production cannot be related to each other at face value. вв installations were indeed found with pottery waste in situ in two nodes, and adjacent to waste in another three nodes. In addition, this type was found on the edges of other sites - a location, which strengthens its industrial character - and at industrial Mazliah. Nevertheless, pottery was fired through a number of methods, and pottery kilns are not the only big-built FI; some might have been bread ovens. First, on the node and nodes-cluster levels, вв installations were only partially connected to pottery waste. Second, our distribution maps from Ramla clearly showed the relation of simple hearths (an inverted jar in one case) with pottery waste even inside the industrial area. Indeed, firing pottery in an open fire was demonstrated in three ethnoarchaeological case studies. Third, sites with fire installations other than вв, such as the Weizmann Institute, provided pottery waste and thus possibly also produced pottery. Fourth, both the furn and mustawqad for bread baking were, according to our reconstruction, big-built apparatuses. The furn even comprised a shelf. The location of one вв in the domestic area of Ramla, with no pottery waste around it, enables its interpretation as a bread oven.

Small-Lined fire installations were divided into two sub-types based on their context and their relations to other elements in the same nodes. Small-Lined FI type 1 is distributed on the northern and eastern parts of the research area. On the contextual level, it was related to structures and conduits. It was rarely related to industrial waste or to other refuse. One less evident spatial correlation was with copper-alloy lollipop-shape objects. Thus, this installation might have been used for baking bread, an interpretation, which accords with literature. Based on the terminological reconstruction, the täbashdān is the most suitable fit for SL1. According to al-Rāzī, the țābashdān was used by mints and recommended for the alchemist, which correlates with its metal finds. Interestingly, the installation appears on most sites, but only in one node, except for Ramla/Mazliah with four nodes. Relying on both the textual and ethnographical evidence, this can be explained as a communal apparatus for several households, or a business that offered baking services, if its small dimensions allow for such an interpretation.

Small-Lined Fi type 2 is highly productive in its nature, consisting of several fire installations together and dug refuse pits nearby. It has a relatively strong presence in
FIGURE 21

Cross-referencing fire installations and glass waste at Ramla 
FIGURE 22

Cross-referencing oil presses, olive pits and Small-Lined F I type 2

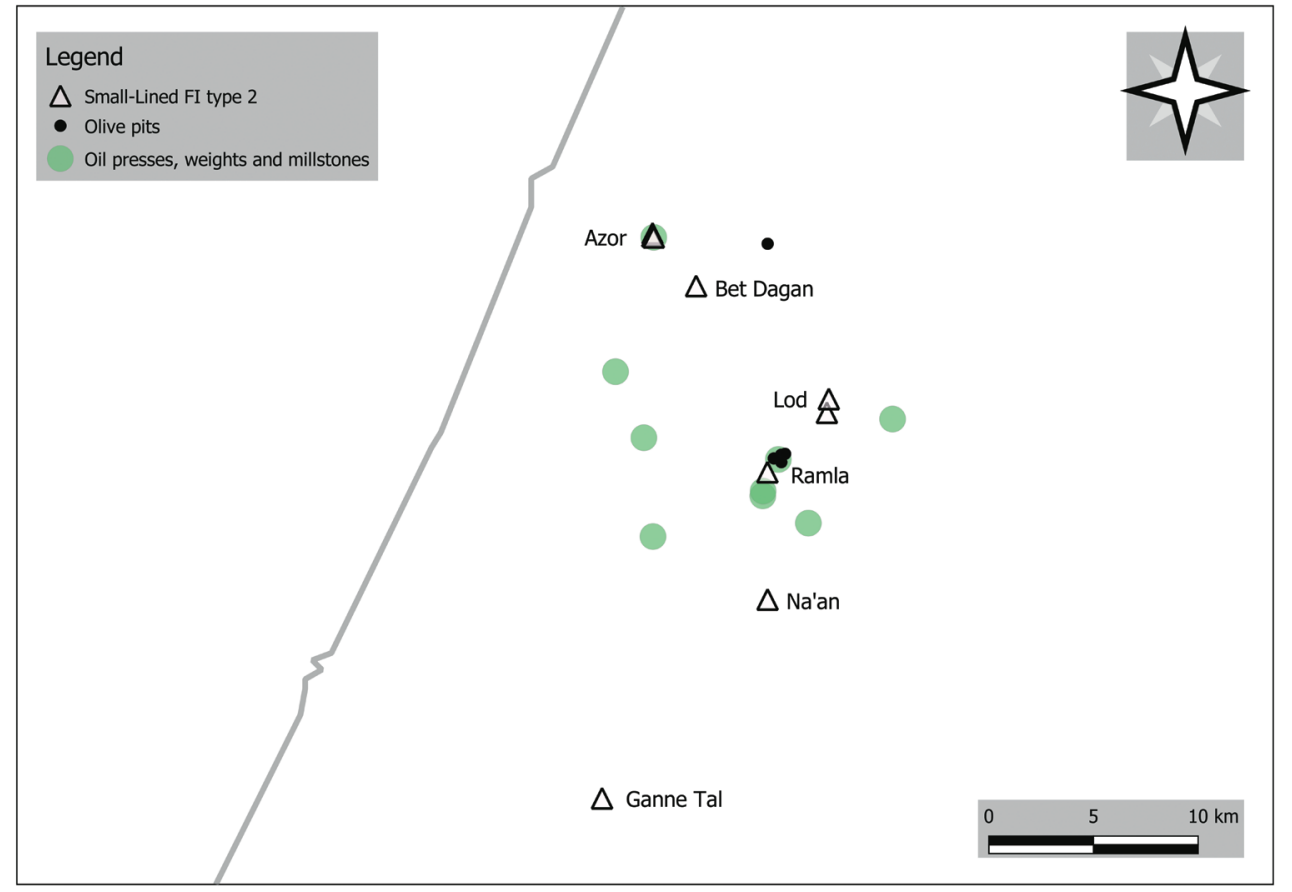

Azor (in three nodes) and Lod (in two). Nonetheless, no strong correlation was found between SL2 and the known crafts - pottery, glass, or metal. One might guess that the products involved were perishable. Two candidates for that speculation are soap and dyes that are assigned to the area in written sources. Both operations necessitated fire for heating liquids. The dug refuse pits that were found in these contexts can be explained by plant material and fruit peels, for dyes (see al-'Alī, 2003: 147-88; Forbes, 1964; al-Shayzarī: 72, translated at Buckley, 1999: 92; Ibn Sīda: vol. 4, 95-6, vol. 11, 20913), ${ }^{13}$ or olive waste, for soap. That waste could be composted under the right conditions or get recycled. The justification for digging refuse pits in these scenarios would be selling the composted waste, and/or sanitation.

One way to test the relation between Small-Lined Fi type 2 and soap manufacture is through remains of olive oil production, as oil was one of the two basic ingredients of soap according to al-Rāzì (Stapleton et al., 1929: 393). Cross-referencing SL2 with possible oil presses (nodes 91, 117, 127, 137, 216, 283), oil-press weights or millstones in secondary use (nodes 140, 176, 212), and olive pits, usually charred (nodes $27,41,54,93,183$ ), shows a poor relation (Fig. 22). ${ }^{14}$ On the one hand, there are no adjacent nodes with fire installations and finds related to olive oil, except for Azor. On the other hand, their distribution is similar, with neighboring domains, which enables some link between the two. While olives could have been transported to these locations, this remains a guess.

An alternative interpretation for SL2 would follow studies on fire installations in earlier periods. In those, the explanations for "domestic" FI clustering in non-domestic contexts were limited to food-production contexts (e.g. centralized bakeries). This line of interpretation, however, has in most cases no support from other finds and rarely from ethno-archaeology. The following example from Aqaba, Jordan, suggests that relating clay installations to food production is so engraved that it restricts excavators from exploring an industrial interpretation. In Areas $\mathrm{M}$ and $\mathrm{O}$ at Aqaba, waste of pottery production from the second century CE was found over a large area (i.e. wasters, slag, and natural clay), with no production loci. No link was suggested between that waste and the large number of clay ovens in the same domains. Instead, the excavator interpreted the clay ovens as domestic (Parker, 2000: 378-9, 2002: 412), and another scholar 
explained them as a commercial bakery (Tomber, 2008: 70). In short, a large number of sL fire installations can certainly be a cluster of bread ovens, but many more interpretations should be considered, involving other perishable remains as well as visible remains from the vicinity.

\section{$7 \quad$ Concluding Remarks}

This case study demonstrates the importance of separating physical remains from "terminology" and "function," after Khoury (1998). It shows that the possible function of an archaeological fire installation does not necessarily correlate with the function of specific "ovens" in texts, even though we imagine both to have the same shape and operation techniques. Nevertheless, a contextual analysis of each of these categories, independently, gives coherent results. Regarding the terminology, some of it is very specific, and signifies particular forms and function, e.g. the portable tābaq, which is a surface placed on fire and utilized for baking bread. Other terms, especially tannūr and atūn, were more general, with several functions and no clear form.

The second arm of the triangle is "form," namely, the archaeological evidence. Following the typology of fire installations, their function can be suggested by tentative analogies. The terminology ancient authors used to describe these fire installations is unknown. The third arm is "function," that is, listing possible activities that require fire. A contextual analysis of ethno-archaeology and texts shows the methods and devices that can be used in fire-related activities. The repetition of specific functions in the two source groups, and in different places, strengthens their possible validity for the archaeological case study.

The case study also highlights the importance of a spatial analysis in archaeology, in addition to varied analogies. In the excavations of early Islamic Cairo (Fusțāț), in areas that were defined as domestic, ovens were absent. Lewicka explains that absence by suggesting that most Cairenes purchased cooked food in the market (Lewicka, 2011: 91-6). Also in the dwelling areas in Ramla, relatively wide domains lacked any built fire installations or even hearths. In contrast to Lewicka, I suggest that in both cases Ramla and Cairo - people used fire devices that leave very few traces that can hardly be tracked by archaeological methods. The ethno-historical and ethno-archaeological evidence supports such an interpretation, together with other spatial analyses.

Ethnography and texts presented many cases of cooking and baking using portable elements such as braziers, or organic ones, like dung, both mostly untraceable. Moreover, built fire installations are scarce in the research area. From most sites, only one or two could be classified, including Jaffa, Lod and Gan Yavne, whereas sites such as Yavne-Yam had none. More support comes from the location of built FI within sites. On several sites, such as Lod, they were concentrated on the edges of the site, which implies their "industrial" nature. In Ramla, most of the built FI were either in the industrial area of Mazliah or around the industrial area of northern Ramla. Fourth, many of the built fire installations were found related to craft waste, and/or in a cluster of adjacent installations, clearly indicating their industrial role. The ethno-archaeological evidence from Dei el-Gharbi in Egypt implies how intensive production of pottery indeed leaves distinct remains.

To conclude, built fire installations and hearths are to be interpreted chiefly as kilns and furnaces. They certainly cannot represent household cooking at face value. Even the common Small-Lined fire installation that archaeologists often call țabūn and interpret 
as a domestic oven seems to be used during early Islam for either the production of another organic product, or as a communal oven. Its location on sites - and mainly its rarity on sites - implies that it was not in domestic use.

The complete list of terms for fire devices in texts does not correlate with the full corpus of fire installations in the archaeological record. Therefore, the link between these two lines of investigation cannot be sketched automatically. The rich domestic activity in the texts is largely "absent" from the archaeological evidence.

\section{About the Author}

Hagit Nol holds a postdoctoral fellowship at the Université libre de Bruxelles, where she conducts research on the distribution of early mosques. Her PhD thesis submitted to the Universität Hamburg focused on settlement patterns in central Israel/Palestine during the 7th-11th centuries. Her research interests involve landscape archaeology, early Islam, the economic and social history of the early medieval period, and the transfer of knowledge and ideas.

\section{Acknowledgements}

This paper is part of my $\mathrm{PhD}$ dissertation submitted to the Universität Hamburg (2019). I am grateful to my supervisors, Stefan Heidemann and Donat Wehner, as well as to Greg Fisher, Anja Rutter, Gil Tsioni, Maria-Louise Sidoroff, Sariel Shalev, Ron Haran, Nelly Beyman, and the anonymous readers, for their suggestions and help.

\section{References}

\section{Primary Literature}

Al-Balādhurī, Aḥmad b. Yahyyā (d. 892). Kitāb Futūh al-buldān. M.J. de Goeje, ed., 1866, Leiden: Brill.

Ibn Sayyār al-Warrāq (the tenth century). Kitāa al-Tabīkh. K. Öhrnberg and S. Mroueh, eds., 1987, Helsinki: The Finnish Oriental Society.

Al-Maqdisī, Muhammad ibn Aḥmad (d. after 99o). Ahssan al-taqāsīm fì márifat al-aqālīm. M.J. de Goeje, ed., Description Imperii Moslemici, second ed. 19o6, Leiden: Brill.

Al-Shayzarī, 'Abd al-Raḥmān ibn Naṣr (d. 1193). Nihāyat al-rutba fì țalab al-ḥisba, second ed. 1981, Bayrūt: Dār al-thaqāfa.

\section{Secondary Literature}

HA-ESI Hadashot Arkheologiyot - Excavations and Surveys in Israel

'Ad, U. (2000). Ramat Gan. HA-ESI 111, pp. * $38-{ }^{*} 39$.

'Ad, U., Golani, A., and Segal, O. (2014). Tel Azor. HA-ESI 126, http://www.hadashot-esi.org.il/ Report_Detail_Eng.aspx?id=12654\&mag_id=121.

Al-'Alī, S. (2003). Al-Mansūjāt wa-l-albisa al-'arabiyya fi-l-'uhūd al-islamiya al-awlā. Bayrūt: Sharikat al-mațbūầt li-l-tawzī‘ wa-l-nashr.

Allan, J.W. (1982). Nishapur: Metalwork of the Early Islamic Period. New York: The Metropolitan Museum of Art.

Arbel, Y. (2011). Hafez Hayyim. HA-ESI 123, http://www.hadashot-esi.org.il/Report_Detail_Eng. aspx?id=1790\&mag_id=118. 
Avi-Yonah, M. (1966). The Holy Land: from the Persian to the Arab Conquest (536 B.C. to A.D. 640), a Historical Geography. Grand Rapids: Baker Book House.

Avitsur, S. (1976). Daily Life in Iretz Israel in the XIX Century. Jerusalem: A. Rubinstein Press and 'Ām Ha-Sēfer Press, in Hebrew.

Avni, G. (2014). The Byzantine-Islamic Transition in Palestine: An Archaeological Approach. Oxford: Oxford University Press.

Avni, G., Avissar, M., Baruch, Y., and Torgë, H. (2008). New Excavations South of the White Mosque. HA-ESI 120, http://www.hadashot-ESI.org.il/Report_Detail_Eng.aspx?id=788\&mag_id=114.

Ayalon, E., and Bashkin-Yosef, N. (2008). Tell Qasile. HA-ESI 12O, http://www.hadashot-esi.org.il/ report_detail_eng.aspx?id=792\&mag_id=114.

Balossi Restelli, F. (2015). Hearth and Home. Interpreting Fire Installations at Arslantepe, Eastern Turkey, from the Fourth to the Beginning of the Second Millennium BCE. Paléorient 41 (1), pp. $127-51$.

Bar-Nathan, R. (2002). The Jacob Kaplan and Haya Ritter-Kaplan Legacy. HA-E SI 114, pp. 130-35, in Hebrew.

Barkan, D., and Jakoel, E. (2010). Ono. HA-ESI 122, http://www.hadashot-esi.org.il/Report _Detail_Eng.aspx?id=1615\&mag_id=117.

Batmaz, A. (2019). A Study of Urartian Red Glossy Pottery Production in Van, Turkey, Using Archaeological, Ethnoarchaeological and Experimental Archaeological Methods. Ethnoarchaeology 11 (1), pp. 34-6o.

Binford, L.R. (1981). Behavioral Archaeology and the "Pompeii Premise." Journal of Anthropological Research 37 (3), pp. 195-208.

Bouchenino, A. (2007). Building Remains and Industrial Installations from the Early Islamic Periods at Khirbat Deiran, Rehovot. 'Atiqot 56, pp. 119-44, in Hebrew.

Brand, Y. (1978). Glass Vessels in Talmudic Literature. Jerusalem: Mossad harav Kook, in Hebrew.

Bresenham, M.F. (1985). Descriptive and Experimental Study of Contemporary and Ancient Pottery Techniques at Bușrā. Berytus 33, pp. 89-101.

Brill, R.H. (1979). A Small Glass Factory in Afghanistan. Glass Art Society Journal 1979, pp. $26-7$.

Buckley, R.P., trans. (1999). The Book of the Islamic Market Inspector, Journal of Semitic Studies Supplement 9. Oxford: Oxford University Press.

Caley, E.R. (1926). The Stockholm Papyrus: An English Translation with Brief Notes. Journal of Chemical Education 4 (8), pp. 979-1002.

Clarke, D.L. (1977). Spatial Archaeology. London: Academic Press.

Crawford, H.E.W. (1981). Some Fire Installations from Abu Salabikh, Iraq (Dedicated to the memory of Margaret Munn-Rankin). Paléorient 7 (2), pp. 105-14.

Crawford, H.E.W. (1983). More Fire Installations from Abu Salabikh. Iraq 45 (1), pp. 32-4.

Crowfoot, G.M. (1932). Pots, Ancient and Modern. Palestine Exploration Fund Quarterly Statement 64 (4), pp. $179-87$.

Dagot, A. (2014). Azor. HA-ESI 126, http://www.hadashot-esi.org.il/Report_Detail_Eng.aspx ?id=12655\&mag_id=121.

Dalman, G. (1928). Arbeit und Sitte in Palästina, Band I: Jahreslauf und Tageslauf, ı. Herbst und Winter. Gütersloh: Der Rufer, Tübingen ed., 2013.

Dalman, G. (1935). Arbeit und Sitte in Palästina, Band IV: Brot, Öl und Wein. Gütersloh: Der Rufer, Tübingen ed., 2013 .

Dothan, M., and Porath, Y. (1982). Ashdod IV: Excavation of Area M. The Fortification of the Lower City, 'Atiqot English Series 15. Jerusalem: Israel Department of Antiquities.

Dunnell, R.C. (1992). The Notion Site. In: J. Rossingnol and L. Wandsnider, eds., Space, Time, and Archaeological Landscapes. New York and London: Plenum Press, pp. 21-41.

Ebeling, J., and Rogel, M. (2015). The Tabun and its Misidentification in the Archaeological Record. Levant 47 (3), pp. 328-49. 
Elisha, Y. (2007). Horbat Harmas. HA-ESI 119, http://www.hadashot-esi.org.il/Report_Detail _Eng.aspx?id=471\&mag_id=112.

Feldstein, A., and Shmueli, O. (2011). Tel Yavne. HA-ESI 123, http://www.hadashot-esi.org.il/ Report_Detail_Eng.aspx?id=1735\&mag_id=118.

Forbes, R.J. (1964). Studies in Ancient Technology, Volume 4, second ed. Leiden: Brill.

Gadot, Y., and Tepper, Y. (2003). A Late Byzantine Pottery Workshop at Khirbet Baraqa. Tel Aviv 3०, pp. $130-57$.

Gat, S. (2007). A Flourishing Arab City: The Economy of Medieval Ramla. Cathedra 123, pp. 39-66, in Hebrew.

Gil, M. (1983). Palestine during the First Muslim Period, Parts II-III: Cairo Geniza Documents, Volume 3. Tel Aviv: Tel Aviv University Press and Ministry of Defense Press, in Hebrew.

The Corning Museum of Glass (1979). Glass Makers of Herat, E. Erwitt, dir., uploaded to YouTube on September 2012, https://youtu.be/BMYE83DJU4Q.

Glick, D., and Gamil, D. (1997). Ramla. Hadashot Arkheologiyot 107, pp. 77-8, in Hebrew.

Golani, A. (2012). Lod. HA-ESI 124, http://www.hadashot-esi.org.il/report_detail_eng.aspx?id $=1938 \&$ mag_id $=119$.

Gorzalczany, A. (2004). A Site of Late Byzantine and Early Islamic periods in Șarafand el-Kharab, Nes Ziyyona. 'Atiqot 46, pp. 37-47, in Hebrew.

Gorzalczany, A. (2006). Ramla (South). HA-ESI 118, http://www.hadashot-esi.org.il/Report _Detail_Eng.aspx?id=341\&mag_id=111.

Gorzalczany, A. (2009). Ramla (South). HA-ESI 121, http://www.hadashot-esi.org.il/Report _Detail_Eng.aspx?id=1195\&mag_id=115.

Gorzalczany, A., and Jakoel, E. (2013). Bet Dagan. HA-ESI 125, http://www.hadashot-esi.org.il/ Report_Detail_Eng.aspx?id=5419\&mag_id=120.

Gorzalczany, A., and Spivak, P. (2008). Ramla (South). HA-ESI 120, http://www.hadashot-esi.org .il/Report_Detail_Eng.aspx?id=820\&mag_id=114.

Gorzalczany, A., Yehuda, L., and Torgë, H. (2010). Ramla (South). HA-ESI 122, http://www .hadashot-esi.org.il/report_detail_eng.aspx?id=1398\&mag_id $=117$.

Govrin, Y. (2013). Excavation at Tsrifin - 2008, Early Islamic Domestic and Industrial Features. NGSBA Archaeology 2, pp. 140-54.

Grabar, O., Holod, R., Knustad, J., and Trousdale, W. (1978). City in the Desert: Qasr al-Hayr East. Cambridge: Harvard University Press.

Gudovitch, S. (2004). Ramla (A). HA-ESI 116, http://www.hadashot-esi.org.il/Report_Detail_Eng .aspx?id=26\&mag_id $=108$.

Al-Hassan, A.H., and Hill, D.R. (1986). Islamic Technology: An Illustrated History. Paris: Unesco and Cambridge University Press.

Henein, N.H. (1997). Poterie et potiers d'Al-Qasr-Oasis de Dakhla, Bibliothèque d'Etude 116. Cairo: Institut Français d'Archéologie Orientale.

Henein, N.H., and Gout, J.-F. (1974). Le verre soufflé en Égypte, Bibliothèque d'Etude 63. Cairo: Institut Français d'Archéologie Orientale.

Hodder, I., and Hutson, S. (2003). Reading the Past: Current Approaches to Interpretation in Archaeology. Cambridge: Cambridge University Press.

Jakoel, E. (2011). Ramla. HA-ESI 123, http://www.hadashot-esi.org.il/Report_Detail_Eng.aspx ?id=1670\&mag_id $=118$.

Kanias, T., and Tueg, R. (2012). Ramla. HA-ESI 124, http://www.hadashot-esi.org.il/report_detail _eng.aspx?id=2104\&mag_id=119.

Khoury, N.N.N. (1998). The Mihrab: From Text to Form. International Journal of Middle East Studies 30 (1), pp. 1-27.

Kogan-Zehavi, E. (2008). Remains of an Early Islamic Settlement and a Hellenistic (Roman?) Tomb at Khirbat Deiran, Rehovot. Atiqot 57, pp. $77^{*}-90^{*}$, in Hebrew. 
Kogan-Zehavi, E., and Hadad, S. (2013). A Building and an Olive Press from the Byzantine-Abbasid Periods at Khirbat el-Thahiriya. 'Atiqot 71, pp. 84-112, in Hebrew.

Konkol, K.L., and Rasmussen, S.C. (2015). An Ancient Cleanser: Soap Production and Use in Antiquity. In: S.C. Rasmussen, ed., Chemical Technology in Antiquity, Acs Symposium Series 1211. Washington: American Chemical Society, pp. 246-9.

Van der Kooij, G., and Wendrich, W. (2002). The Potters of el-Fustat (Cairo) and el-Nazla (Fayoum). In: W. Wendrich and G. van der Kooij, eds., Moving Matters: Ethnoarchaeology in the Near East. Proceedings of the International Seminar held at Cairo, 7-10 December 1998, CNWS Publications 111. Leiden: cNWs, pp. 147-58.

Lagercrantz, O. (1913). Papyrus Graecus Holmiensis (P.Holm). Recepte für Silber, Steine und Purpur. Uppsala and Leipzig: Akademiska Bokhandeln and Otto Harrassowitz.

LaMotta, V.M., and Schiffer, M.B. (1999). Formation Processes of House Floor Assemblages. In: P.M. Allison, ed., The Archaeology of Household Activities. London and New York: Routledge, pp. $19-29$.

Lewicka, P.B. (2011). Food and Foodways of Medieval Cairenes: Aspects of Life in an Islamic Metropolis of the Eastern Mediterranean. Leiden and Boston: Brill.

London, G. (2000). Continuity and Change in Cypriot Pottery Production. Near Eastern Archaeology 63 (2), pp. 102-10.

Lyons, D., and Casey, J. (2016). It's a Material World: The Critical and On-Going Value of Ethnoarchaeology in Understanding Variation, Change and Materiality. World Archaeology 48 (5), pp. 6o9-27.

Masarwa, D. (2011). Ramla (Northwest). HA-ESI 123, http://www.hadashot-esi.org.il/Report _Detail_Eng.aspx?id=1767\&mag_id=118.

McQuitty, A. (1984). An Ethnographic and Archaeological Study of Clay Ovens in Jordan. Annual of the Department of Antiquities of Jordan 28, pp. 259-67.

Melkawi, A., 'Amr, Kh., and Whitcomb, D.S. (1994). The Excavation of Two Seventh Century Pottery Kilns at Aqaba. Annual of the Department of Antiquities of Jordan 38, pp. 447-68.

Messika, M. (2006). An Early Islamic Period Site at Kafr Jinnis near Lod. Salvage Excavation Report 3, pp. 84-112.

Mulder-Heymans, N. (2002). Archaeology, Experimental Archaeology and Ethnoarchaeology on Bread Ovens in Syria. Civilisations 49, pp. 1-21.

Nasrallah, N. trans. (2010). Annals of the Caliphs' Kitchens. Ibn Sayyār al-Warrāq's Tenth-Century Baghdadi Cookbook, English Translation. Leiden and Boston: Brill.

Nicholson, P., and Patterson, H. (1985). Pottery Making in Upper Egypt: An Ethnoarchaeological Study. World Archaeology 17 (2), pp. 222-39.

Nol, H. (2020). Cities, Ribāțs and Other Settlement types in Palestine from the Seventh to the Early Thirteenth Century: An Exercise in Terminology. Al-Masāq. 32 (3), pp. 243-74.

Nol, H. (forthcoming). The Archaeological Narratives of Ramla from the 7 th to the 11th Century: Experimenting with Big Data. In: J. Vroom and I. Simpson, eds., Material Entanglements in the Islamic World: New Approaches to Islamic Archaeology \& Ceramics, Symposium held at Leiden University on November 19th-21st, 2018, Medieval and Post-Medieval Mediterranean Archaeology Series. Turnhout: Brepols.

Ochsenschlager, E. (1974). Mud Objects from al-Hiba: A Study in Ancient and Modern Technology. Archaeology 27 (3), pp. 162-74.

Ovadia, A. (1962). Kh. El-Bad. Hadashot Arkheologiyot 4, pp. 10-11.

Parker, B.J., and Uzel, M.B. (2007). The Tradition of Tandır Cooking in Southeastern Anatolia: An Ethnoarchaeological Perspective. In: T. Takaoğlu, ed., Ethnoarchaeological Investigations in Rural Anatolia, Volume 4. Istanbul: Ege Yainları, pp. 7-43.

Parker, S.T. (200o). The Roman 'Aqaba Project: The 1997 and 1998 Campaigns. Annual of the Department of Antiquities of Jordan 44, pp. 373-94. 
Parker, S.T. (2002). The Roman 'Aqaba Project: The 2000 Campaign. Annual of the Department of Antiquities ofJordan 46, pp. 409-28.

Peilstöcker, M. (1998). Yaffo, Miragoza Street. Hadashot Arkheologiyot 108, p. 71, in Hebrew.

Peilstöcker, M., and Kapitikon, A. (1998). Beit Dagan. Hadashot Arkheologiyot 108, pp. 84-5.

Peilstöcker, M., Re'em, A., Haddad, E., and Gendelman, P. (20o6). Yafo, Flea Market Complex. HA-ESI 118, http://www.hadashot-esi.org.il/Report_Detail_Eng.aspx?id=431\&mag_id=111.

Rauchberger, L. (2009). Azor. HA-ESI 121, http://www.hadashot-esi.org.il/Report_Detail_Eng .aspx?id=1181\&mag_id=115.

Rizqallah, F., and Rizqallah, K. (1978). La preparation du pain dans un village du Delta Égyptien (province de Charqia). Cairo: Institut français d'archéologie orientale.

Rova, E. (2014). Tannurs, Tannur Concentrations and Centralized Bread Production at Tell Beydar and Elsewhere: An Overview. In: L. Milano, ed., Paleonutrition and Food Practices in the Ancient Near East: Towards a Multidisciplinary Approach. Padova: S.A.R.G.o.N. Editrice e Libreria, pp. 121-70.

Schiffer, M.B. (1987). Formation Processes of the Archaeological Record, 1996 ed. Salt Lake City: University of Utah Press.

Shalev, S., and Freund, M. (2002). Using a Traditional Metal Workshop in Modern Cairo as a "Ready-Made" Lab for Studying Aspects of Early Islamic Metallurgy. Bulletin of the Israeli Academic Center in Cairo 25, pp. 21-30.

Shavit, E. (2009). A Complex of Two Wine Presses in Rishon Le-Zion. In: E. Ayalon, R. Frankel and A. Kloner, eds., Oil and Wine Presses in Israel from the Hellenistic, Roman and Byzantine Periods, BAR International Series 1972. Oxford: Archaeopress, pp. 239-42.

Shor, Y. (1999). Ramla, Ha-Palmah Compound. HA-E SI 110, pp. 71-2, in Hebrew.

Sidoroff, M.-L. (2015). An Ethnoarchaeological Study of the Zizia Pottery Factory in Jizza, Jordan. Ethnoarchaeology 7 (2), pp. 86-113.

Sion, O. (2009). Ramla (East). HA-ESI 121, http://www.hadashot-esi.org.il/Report_Detail_Eng .aspx?id=1150\&mag_id=115.

Smogorzewska, A. (2012). Fire Installations in Household Activities. Archaeological Study from Tell Arbid (North-East Syria). Paléorient 38 (1/2), pp. 227-47.

Stapleton, H.E., Azo, R.F., and Husain, H.M. (1929). Chemistry in 'Iraq and Persia in the Tenth Century A.D. Memoirs of the Royal Asiatic Society of Bengal 8, pp. 317-418. Rep. 2002 in: F. Sezgin, ed. Muhammad ibn Zakarīy $\bar{a}^{\prime}$ Ar-Rāzi, Texts and Studies I, Natural Sciences in Islam 73. Frankfurt am Main: Institute for the History of Arabic-Islamic Science.

Van der Steen, E.J. (1991). The Iron Age Bread Ovens from Tell Deir 'Alla. Annual of the Department of Antiquities of Jordan 35, pp. 135-53.

Tal, O., and Taxel, I. (2008). Ramla (South): An Early Islamic Industrial Site and Remains of Previous Periods, Salvage Excavation Report 5. Tel Aviv: Tel Aviv University.

Taxel, T. (2007). Stratigraphy and Architecture. In: R. Gophna, I. Taxel and A. Feldstein, Kafr Ana: A Rural Settlement in the Lod Valley, Salvage Excavation Report 4. Tel Aviv: Tel Aviv University.

Thomas, D.H. (1975). Nonsite Sampling in Archaeology: Up the Creek Without a Site?. In: J.W. Mueller, ed. Sampling in Archaeology, second ed. 1979. Tucson: The University of Arizona Press, pp. 61-81.

Tomber, R. (2008). Indo-Roman Trade: From Pots to Pepper. London: Gerald Duckworth.

Torgë, H. (2003). Lod. HA-ESI 115, pp. 57-9.

Torgë, H. (2005a). Azor. HA-ESI 117, http://www.hadashot-esi.org.il/Report_Detail_Eng.aspx?id $=131 \&$ mag_id $=110$.

Torgë, H. (2005b). Ramla (B).HA-ESI 117, http://www.hadashot-esi.org.il/Report_Detail_Eng.aspx ?id=279\&mag_id=110.

Torgë, H. (2010). Khirbat el-Ni'ana. HA-ESI 122, http://www.hadashot-esi.org.il/Report_Detail_ Eng.aspx?id=1455\&mag_id=117. 
Torgë, H. (2011). Ramla, Kokhav Ha-Zafon Neighborhood. HA-ESI 123, http://www.hadashot-esi. org.il/Report_Detail_Eng.aspx?id=1899\&mag_id=118.

Tsioni, G. (2008). A Salvage Excavation at Khirbet Ni'ana. Contract Archaeology Reports 3, pp. 33-66, in Hebrew.

Tueg, R., and Arnon, Y.D. (2011). Ramla. HA-ESI 123, http://www.hadashot-esi.org.il/Report _Detail_Eng.aspx?id=1918\&mag_id=118.

Volynsky, F. (2009). Ramat Gan. HA-ESI 121, http://www.hadashot-esi.org.il/Report_Detail_Eng .aspx?id=1203\&mag_id $=115$.

Volynsky, F., and Talmi, L. (2011). Rehovot, Kramim Neighborhood. HA-ESI 123, http://www .hadashot-esi.org.il/Report_Detail_Eng.aspx?id=1911\&mag_id=118.

Waines, D. (1991). Maṭbakh. Encyclopaedia of Islam, second ed., Volume 6, pp. 8o7-9.

Weksler-Bdolah, S. (2000). Yad Benyamin. HA-E SI 112, pp. 123-5, in Hebrew.

Wendrich, W. (2002). Moving Matters, an Introduction. In: W. Wendrich and G. van der Kooij, eds., Moving Matters: Ethnoarchaeology in the Near East. Proceedings of the International Seminar held at Cairo, 7-10 December 1998, CNWS Publications 111. Leiden: CNWS, pp. 7-12.

Whitcomb, D.S. (1988). Aqaba "Port of Palestine on the China Sea". Amman: al-Kutba.

Wikinson, C.K. (1986). Nishapur: Some Early Islamic Buildings and Their Decoration. New York: The Metropolitan Museum of Art.

Wolff, S., and Shavit, A. (1999). Tel Hamid. HA-ESI 109, p. *68.

Wylie, A. (1985). The Reaction against Analogy. Advances in Archaeological Method and Theory 8, pp. 63-111.

Yannai, E. (2014). Yavne. HA-ESI 126, http://www.hadashot-esi.org.il/Report_Detail_Eng. aspx?id=13677\&mag_id=121.

Zaouali, L. (2007). Medieval Cuisine of the Islamic World, English ed. Berkeley: University of California Press.

Zapata Peña, L., Peña-Chocarro, L., Ibáñez Estévez, J.J., and González Urquijo, J.E. (2003). Ethnoarchaeology in the Moroccan Jebala (Western Rif): Wood and Dung as Fuel. In: K. Neumann, A. Butler and S. Kahlheber, eds., Food, Fuel and Fields: Progress in African Archaeology, Africa Praehistorica 15. Köln: Heinrich Barth Institut, pp. 163-75.

\section{Notes}

Recently, archaeologists have identified an early Islamic "soap factory" in southern Israel, but the data and the reasoning for this identification await publication. For the press release, see: https://www.time sofisrael.com/earliest-soap-factory-in-israel-discovered-in-negev-shows-seeds-of-early-islam/.

2 Teshûvôt Rav Natrona'î Ga'ôn - Brûdî (Ôfeq), Ôrah Ḥayîm, simānîm q.k.g., q.k.d., s.d., s.h.; Te shûvôt

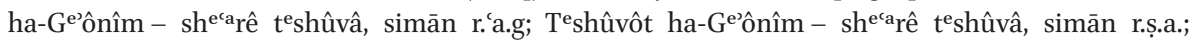

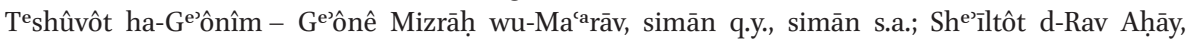
pārāshat ș.w., shểîltâ '.z.

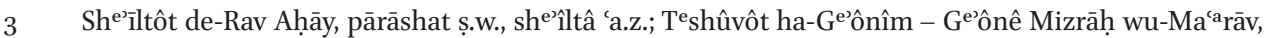
simān q.y.

She’īltôt de-Rav Ahāy, pārāshat mațôt, she'îltâ q.l.z.

Teshûvôt ha-Gềnîm - G ${ }^{\mathrm{e}}$ ônê Mizrāh wu-Ma ${ }^{\mathrm{c} a}$ rāv, simān n.w.

Teshûvôt ha-Gènôim - $\mathrm{G}^{\mathrm{e}}$ ônê Mizrāḥ wu-Ma ${ }^{\mathrm{c} a}$ rāv, simān q.y.

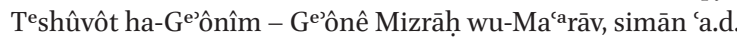

Te shûvôt Rav Natrona'î Ga’ôn - Brûdî (Ôfeq), Ôraḥ Ḥayîm, simānîm q.k.g., q.k.d.

Sēfer Halakhôt Ge dôlôt, simān z. - Hilkhôt Shabbāt, pereq 17.

10 Teshûvôt ha-Gèônîm - Ge'ônê Mizrāḥ wu-Macarāv, simān q.y.; Teshûvôt Rav Natrona’î Ga’ôn - Brûdî (Ôfeq), Ôrạ̣ Ḥayîm, simān s.g.; Sēfer Halakhôt Gedôlôt, simān z. - Hilkhôt Shabbāt, pereq shelīshī; Safrâ shemînî, pārāshâ ḥ., pereq y.

11 In the Hebrew script, the letters $k$ and $b$ look similar, and both words make sense in this context.

12 Sēfer Halakhôt G ${ }^{\mathrm{e}}$ dôlôt, simān n.h. - Hilkhôt Yayin Nesekh; Te shûvôt ha-Ge'ônîm - she ${ }^{\mathrm{e}^{\mathrm{a}}}$ rê te ${ }^{\mathrm{e}}$ shûvâ, simān r.n.g. 
13 Talmûd Bavlî masekhet shabbāat pereq ț - āmar Rabbî 'Aqîvâ.

14 Node 27: Tueg and Arnon, 2011. Node 41: Sion, 2009. Node 54: Torgë, 2005b. Node 91: Glick and Gamil, 1997. Node 93: Shor, 1999. Node 117: Wolff and Shavit, 1999. Node 127: Kogan-Zehavi and Hadad, 2013. Node 137: Tal and Taxel, 2008: 53. Node 140: Gorzalczany, 2009. Node 176: Rauchberger, 2009. Node 183: Taxel, 2007: 14. Node 212: Shavit, 2009. Node 216: Gorzalczany, 2004. Node 283: Bouchenino, 2007: 122, figs. $3-4$. 